\title{
Naturally occurring glucosinolates and isothiocyanates as a weapon against chronic pain: potentials and limits
}

\author{
Elena Lucarini (iD) - Laura Micheli • Lorenzo Di Cesare Mannelli • \\ Carla Ghelardini
}
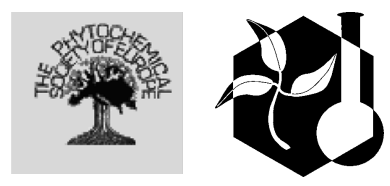

Received: 1 September 2021 / Accepted: 2 February 2022/Published online: 22 February 2022

(C) The Author(s) 2022

\begin{abstract}
Investigation into glucosinolates (GLs) therapeutic effects boasts a long history, which began with the evidence that their hydrolysis-derived isothiocyanates (ITCs) could exert cytoprotective effects through the modulation of both the inflammatory response (NF-kB pathway) and the oxidative stress (Nrf2/ARE pathway), two processes largely involved in the pathogenesis of chronic pain syndromes. GLs and ITCs are also able to modulate the activity and the expression of several targets involved in pain regulation, like opioid receptors. Recently, ITCs turned out to be slow- $\mathrm{H}_{2} \mathrm{~S}$ donors in vivo, able to directly modulate the activity of a subtype of $\mathrm{K}_{\mathrm{V}} 7$ potassium channels involved in the transmission of painful stimuli, providing a further incentive to their employment in pain management. Nevertheless, some controversies exist in the use of ITCs for pain relief considering their ability to positively modulate the activity of TRPA1 receptors. This review focuses on the preclinical and clinical evidence attesting the beneficial effects of GLs and their derivatives ITCs in chronic inflammatory and neuropathic conditions. In this context, the mechanisms underlying the ability of GLs and ITCs to modulate pain perception and,
\end{abstract}

E. Lucarini $(\bowtie) \cdot$ L. Micheli ·

L. Di Cesare Mannelli · C. Ghelardini

Department of Neuroscience, Psychology, Drug Research and Child Health (NEUROFARBA), Pharmacology and Toxicology Section, University of Florence, Viale

Gaetano Pieraccini 6, 50139 Florence, Italy

e-mail: elena.lucarini@unifi.it besides, to prevent the establishment of chronic pain will be described along with their pharmacokinetics and toxicological profile. Finally, other possible mechanisms hidden behind GLs efficacy on pain will be discussed.

Keywords Glucosinolates · Isothiocyanates · Pain · $\mathrm{H}_{2} \mathrm{~S} \cdot$ Neuropathy $\cdot$ Inflammation

\section{Chronic pain}

"Divinum opus est sedare dolorem" (Hippocrates).

Pain represents a clinical burden, considering its high prevalence among patients and the lack of adequate therapies in most cases (Mäntyselkä et al. 2001). Although pain itself is not life-threatening, the development of chronic pain has a strong impact on quality of life, therefore its management represents a health priority in patients (Goldberg and McGee 2011). Chronic pain can manifest in two different forms, namely as a primary or secondary syndrome. Primary chronic pain is considered a proper disease whereas, chronic secondary pain arises as a symptom of another disease (cancer, diabetic neuropathy, inflammatory bowel disease, or arthritis), though it continues after the healing of the underlying disease (Treede et al. 2019). It has been estimated that the development of chronic pain occurs in $\sim 20 \%$ of the adults in Europe (Breivik et al. 2006) as well as in US 
(Dahlhamer et al. 2018) and it is accompanied by a huge health and economic burden (Barham 2012; Gaskin and Richard 2012).

Chronic pain syndromes can differ in the aetiology, modes of manifestations, and response to pain medication (Treede et al. 2019). Chronic musculoskeletal pain, affecting bones, joint or muscles (Perrot et al. 2019) can result from inflammatory processes, autoimmune, or metabolic diseases, or can be secondary to motor nervous system diseases (e.g., Parkinson's disease) (Nicholas et al. 2019). Besides, neuropathic pain is due to a direct damage to the nervous system, like that caused by tissue injury, metabolic disorders (diabetes), infections (HIV, herpes zoster), chemotherapeutic agents (platinum drugs, taxanes, vinca alkaloids) or alcohol abuse (Jensen et al. 2011). The etiopathogenesis of neuropathic pain makes it unresponsive to almost all the painkiller drugs (Treede et al. 2008). Finally, chronic pain can also originate from the viscera (e.g., intestine or uterus) as a consequence of mechanical factors (obstruction), vascular mechanisms (ischemia), or persistent inflammation (Aziz et al. 2019; Häuser et al. 2020). Visceral pain can also be relate to a disruption of the microbiota homeostasis (O'Mahony et al. 2017; Vila et al. 2018) or to the presence of cancer in internal organs (Bennett et al. 2019).

The treatment of chronic pain depends on pain subtype. Conditions primarily associated with inflammation (e.g., osteoarthritis) are preferably treated with acetaminophen and non-steroidal anti-inflammatory drugs, whereas pain with a neuropathic base is treated with tricyclic antidepressants, selective-serotonin/noradrenaline reuptake inhibitors, and Alpha 2 Delta $(\alpha 2 \delta)$ ligands, namely gabapentin and pregabalin (Hylands-White et al. 2017). Despite the large number of medications available for the treatment of pain, their limited efficacy in chronic conditions and several side effects, particularly in the elderly (Crofford 2013), led to investigate novel strategies to safely employ in long-term therapies. Among them, many natural products have been investigated with the aim of combining different mechanisms of action to achieve greater efficacy. The broad range of beneficial effects (anti-inflammatory, antioxidant, neuroprotective, and anti-hyperalgesic) endowed by glucosinolates (GLs), make them the ideal natural tool in the management of chronic pain syndromes, which in most cases have a complex aetiology.

\section{Glucosinolates and isothiocyanates}

Glucosinolates ( $S$ - $\beta$-thioglucoside $N$-hydroxysulfate; GLs) are sulfur-containing phytochemicals mainly found in cruciferous (Brassicaceae), most of which are edible plants (Holst and Williamson 2004a). GLs content in these vegetables depends on several factors including the cultivation region and conditions, the plant part, the degree of development, as well as genetic and environmental factors. In foliage GLs content range from 1000 to $3000 \mathrm{ppm}$ (Brussels sprouts), while the concentrations of GLs in roots and seeds can be higher (30,000-60,000 ppm) (Agerbirk and Olsen 2012). Starting from sinalbin (Robiquet and Boutron 1831), hundreds of different GL structures were discovered in nature (Sønderby et al. 2010), which differ each other for the precursor as well as for the secondary modifications occurring on their sugar moieties (e.g.oxidation, methoxylation, sulfation, glucosylation) (Agerbirk and Olsen 2012; Radojčić Redovniković et al. 2008). In plants, the $\beta$-thioglucosidase enzyme myrosinases (EC 3.2.1.147) is responsible for GLs metabolism. This enzyme, which is physically segregated from GLs in plants, once released after mastication, cutting or cooking, leads to the hydrolysis of GLs into glucose and the unstable aglycones, which then turn into isothiocyanates (ITCs) or indoles, based on their side chain. In mammalian tissues conversion of GLs to ITCs is possible thanks to the gastrointestinal bacteria (Shapiro et al. 1998). Besides, several physico-chemical factors (e.g., $\mathrm{pH}$, the number of double bonds in the side chains, the presence of ferrous ions, the epithiospecifier protein), instead determine the conversion of ITCs and indoles into other compounds, such as epthionitriles, nitriles and thiocyanates. Nevertheless, ITCs have been recognized as the active compounds responsible for the effects of GLs on human health, which are likely the results of a plurality of molecular mechanisms, (modulation of xenobiotic metabolism and inflammation, the regulation of cell cycle and oxidative stress, as well as the regulation of epigenetic events), many of which participate to chronic pain development and persistence (Capuano et al. 2017). Moreover, recent evidence attested the ability of GLs and ITCs to modulate the activity of channels and receptors involved in pain transmission (Lucarini et al. 2018b, 2019a). In the next paragraphs we describe in detail the beneficial effects of these phytocompounds 
and their positive implications in the treatment of chronic pain.

\section{GLs, ITCs and pain}

Brassicaceae family encloses several plants which have been employed in medicine as analgesics. Among the Brassicaceae-derived phytochemicals, the most studied in the context of pain are glucoraphanin and its derived ITC, sulforaphane, whose effects on pain involve the activation of Nrf2, as well as the inhibition of the NF- $\kappa \mathrm{B}$ signalling pathway (as described in details in the following sections), and therefore the downregulation of cytokines expression (Guerrero-Beltrán et al. 2012b). Sulforaphane has been observed to relieve pain associated with diabetes or osteoarthritis in preclinical models, in part, by modulating the inflammatory response (Davidson et al. 2013; Negi et al. 2011). Sulforaphane has been also reported to upregulate the expression of opioid- $\mu$ receptor (Wang and Wang 2017) and enhance morphine analgesic effect (Ferreira-Chamorro et al. 2018; Redondo et al. 2017). In a similar manner, broccoli sprouts and sulforaphane were able to reduce abdominal pain by the activation of $\mu$ opioid receptors, as proven by naltrexone-mediated inhibition (Distrutti et al. 2010). The same compounds demonstrated to have further modulatory activity on visceral motor functions in vitro where they showed a spasmolytic activity on pig ileum similar to papaverine (Guadarrama-Enríquez et al. 2018). Accordingly, sulforaphane has been reported to alleviate bone pain and enhance morphine potency in rats with cancer. Interestingly, also in this case, the anti-hyperalgesic effects of sulforaphane were partially blocked by opioid receptor antagonists (Fu et al. 2021). ITC moiety might influence opioid receptors activity by irreversibly binding the sulfhydryl groups on their constituent amino acids (cysteine or lysine), which may control receptors conformation and functionality. Anyway, it has been observed that the introduction of the ITC-group into 1-position of fentanyl analogues, increased their selectivity for $\delta$ opioid receptor but decreased their analgesic activity (Bi-Yi et al. 1999).

Di Cesare Mannelli et al. (2017) and Lucarini et al. (2018a, b) observed that synthetic (allyl-, phenyl- and 3-carboxyphenyl-ITC) and natural (sulforaphane) ITC-based compounds, were able to counteract chemotherapy-induced neuropathic pain, showing a similar efficacy and a tenfold greater potency (10times) than duloxetine and pregabalin, the reference drug in the management of neuropathies associated with chemotherapy (Hershman et al. 2014). Noteworthy, morphine is ineffective against oxaliplatin-dependent pain (Mannelli et al. 2017), thus excluding opioid receptors from the mechanisms underlying ITCs-mediated effects. Interestingly, these compounds have been described as slow $\mathrm{H}_{2} \mathrm{~S}$ donors (Citi et al. 2014; Martelli et al. 2014). The involvement of $\mathrm{H}_{2} \mathrm{~S}$ release in the antinociceptive effects of ITCs has been proven by the fact that co-administering two $\mathrm{H}_{2} \mathrm{~S}$ scavengers, like haemoglobin and glutathione, strongly reduced their pain-relieving efficacy (Mannelli et al. 2017). At the same time, the antinociceptive effects of ITCs was almost completely reverted by XE991 (a selective blocker of Kv7 channels). Taken together this evidence suggest that the activation of $\mathrm{Kv} 7$ potassium channels might account for the $\mathrm{H}_{2} \mathrm{~S}$ mediated anti-hyperalgesic effects of ITCs. Subsequently, the efficacy of ITCs against chronic pain has been confirmed in other preclinical models of neuropathy induced by ligation of sciatic nerve or diabetes, respectively, as well in the experimental model of osteoarthritis induced by injecting monoiodoacetate into joint space (Lucarini et al. 2018a, 2019b). Moringin, a natural ITC present in $M$. oleifera Lam., effectively reduced the typical neuropathic pain associated to multiple sclerosis in mice (Giacoppo et al. 2017a). Likewise, a series of semisynthetic derivatives of Moringa ITCs showed a dosedependent antinociception in a model of formalininduced joint inflammation (Dos Santos et al. 2018).

Some natural ITCs (such as allyl-ITC, AITC) were reported to modulate the activity of TRPA1 channels which are known to be involved in the pathophysiology of several painful conditions (Logashina et al. 2019). Anyway, high micromolar concentrations of AITC are employed to reproduce animal models of pain, and itch (Andersen et al. 2017; Martelli et al. 2020a). This implies that AITC concentrations need to be increased further to induce TRPA1 desensitization and analgesia, thus excluding the possibility that TRPA1 activation is the main mechanisms of action by which ITCs can relieve pain. The activation of TRPA1 channels, as well as the opening of voltagedependent calcium channels, also fuels the controversy about the role played by $\mathrm{H}_{2} \mathrm{~S}$ on pain regulation 
(Roa-Coria et al. 2019; Tsubota-Matsunami et al. 2012), though the gasotransmitter has been reported to activate TRPA1 channels at concentrations much higher than the physiological one (Logashina et al. 2019).

In addition to exert an acute antihyperalgesic effect, the repeated treatment with glucoraphanin and sulforaphane was able to counteract the development of neuropathic pain caused by the administration of a chemotherapeutic agent in mice (Lucarini et al. 2018b). As well, sulforaphane intrathecally administered resulted able to counteract inflammation and oxidative stress caused by spinal nerve transection, concomitantly blocking the development of neuropathic pain (Kim et al. 2010). These properties can be attributed to the well-known neuroprotective effects of GLs. In another work, a defatted seed meal of Eruca sativa, enriched in GLs (mainly glucoerucin), resulted effective in relieving neuropathic pain caused by diabetes in mice after an acute administration, without reverting neuropathic pain after a repeated treatment (Lucarini et al. 2019b). This evidence confirms that administering GLs can counteract the pathophysiological mechanisms underlying neuropathy development, but it is much less effective in reverting neuropathy when it is already established, highlighting the importance of using these compounds from the earliest stages of the disease. Moreover, the animals developed no tolerance to the anti-hyperalgesic effect of Eruca sativa meal after the repeated treatment (Lucarini et al. 2019b). This represents an great advantage over treatment with others pain-relieving drugs, such us opioids (Christie 2008). In the next paragraphs we will deepen the mechanism which have been proven to be involved in the anti-hyperalgesic effect of GLs, as well as the mechanisms which might participate in it.

\section{GLs as anti-inflammatory/antioxidants agents}

Pain is a cardinal feature of inflammation and, conversely, the persistence of pain is often caused by a chronic neuroinflammation. Non-neuronal cells, such as immune cells and glial cells, actively involved in the regulation of inflammatory responses, participates in the pathogenesis and persistence of chronic pain ( $\mathrm{Ji}$ et al. 2016). On this base, there appears to be clear therapeutic potential for chronic pain management of compounds endowed with strong anti-inflammatory and antioxidant activities, like GLs and ITCs, which effectively counteracted inflammatory processes in different in vitro and in vivo models of disease. GLs and their metabolites, ITCs and indoles, have been shown to exert multiple chemopreventive effects (Table 1). Indeed, ITCs and indoles regulate the activity of both Nuclear erythroid 2-related factor 2 (Nrf2) and Nuclear factor- $\kappa \mathrm{B}(\mathrm{NF}-\kappa \mathrm{B})$ which have a main role in oxidative stress and inflammation, respectively (Esteve 2020; Guerrero-Beltrán et al. 2012a; Wu et al. 2004). These phytochemicals can inhibit nuclear factor NF-kB translocation, preventing proinflammatory cytokine production (IL-1ß and TNFa) and andoxidative species generation (i-NOS, nitrotyrosine and PARP) (Saleh et al. 2021). Oxidative stress and inflammation are tightly connected, one of which can be triggered by the other (Biswas 2016), they thus occur togheter in a large number of diseases. Moreover, redox imbalance contributes to consolidate pain by exacerbating inflammatory responses (Gunn et al. 2020; Kaushik et al. 2020; Marchev et al. 2017; Sánchez-Domínguez et al. 2015). Anyway, increasing evidence in litterature attests that oxidative stress has a key role in the pathogenesis of neuropathic pain in which inflammatory processes are not necessarily involved (Areti et al. 2014; Hosseini and Abdollahi 2013; Mannelli et al. 2012; Naik et al. 2006). ITCs can either directly interact with sulfhydryl residues on Keap1, the cytoplasmatic repressor of Nrf2, determining the release of the factor and its translocation into the nucleus, or activate the MAPK pathway, indirectly causing the phosphorylation of Keap1 and release of $\mathrm{Nrf2}$ (Hu et al. 2004). Once translocated into the nucleus, Nrf2 activates ARE-responsive genes and induces the phase II response (Dinkova-Kostova et al. 2002). However, the sole anti-inflammatory or antioxidant activity displayed by these phytochemicals can not entirely explain their pain-relieving efficacy, and this led to the search for additional mechanisms.

\section{GLs as neuroprotective agents}

Oxidative stress and chronic inflammation are commonly partners in the pathogenesis of central nervous system diseases, against which both GLs and ITCs exerted protective effects (Table 2). Among GLs and 
Table 1 Antioxidants and anti-inflammatory effects of the sources of GLs and ITCs

\begin{tabular}{|c|c|c|c|}
\hline Source of GLs & Effects & Subjects & References \\
\hline $\begin{array}{l}\text { Raphanus sativus (Radish) } \\
\text { extracts from the aerial and } \\
\text { underground parts }\end{array}$ & Disease recovery or improvement & $\begin{array}{l}\text { Folk medicine-based management } \\
\text { of stomach disorders, urinary } \\
\text { infections, hepatic inflammation, } \\
\text { cardiac disorders, and ulcers }\end{array}$ & $\begin{array}{l}\text { Manivannan } \\
\text { et al. } \\
\text { (2019) }\end{array}$ \\
\hline $\begin{array}{l}\text { Moringa oleifera (Moringa) } \\
\text { water extract from leaves }\end{array}$ & $\begin{array}{l}\text { Attenuated expression of iNOS and } \\
\text { IL- } 1 \beta \text { and production of nitric oxide } \\
\text { and TNF } \alpha\end{array}$ & Macrophages & $\begin{array}{l}\text { Waterman } \\
\text { et al. } \\
\text { (2014) }\end{array}$ \\
\hline $\begin{array}{l}\text { Armoracia rusticana (Horseradish) } \\
\text { extracts from roots }\end{array}$ & Anti-inflammatory properties & LPS-stimulated macrophages & $\begin{array}{l}\text { Marzocco } \\
\text { et al. } \\
(2015)\end{array}$ \\
\hline $\begin{array}{l}\text { Nasturtium officinale } R . B r \\
\text { (Watercress) extract containing } \\
\text { standardized GLs }\end{array}$ & $\begin{array}{l}\text { Decrease of lipid peroxidation, } \\
\text { protein carbonyl, catalase, } \\
\text { superoxide dismutase, and } \\
\text { C-reactive protein levels }\end{array}$ & People with physical disabilities & $\begin{array}{l}\text { Clemente } \\
\text { et al. } \\
(2020)\end{array}$ \\
\hline Matthiola arabica ITCs rich fraction & $\begin{array}{l}\text { Reduction of oxidative stress, } \\
\text { inflammatory and fibrosis markers }\end{array}$ & Rat model of liver fibrosis & $\begin{array}{l}\text { Mohammed } \\
\text { et al. } \\
\text { (2017) }\end{array}$ \\
\hline $\begin{array}{l}\text { Magliasa } \\
\text { traditional Iranian formula from } \\
\text { seeds of Lepidium sativum, Linum } \\
\text { usitatissimum, and Allium } \\
\text { ampeloprasum cv. Porrum, the fruit } \\
\text { of Bunium persicum and } \\
\text { Terminalia chebula, and the gum } \\
\text { resin of Pistacia lentiscus }\end{array}$ & $\begin{array}{l}\text { Improvement of the colonic } \\
\text { histopathological score with a } \\
\text { reduction of TNF- } \alpha \text {, IL-1 } \beta, \text { MPO } \\
\text { and lipid peroxidation in the gut }\end{array}$ & Rat model of colitis & $\begin{array}{l}\text { Rahimi et al. } \\
\text { (2013) }\end{array}$ \\
\hline $\begin{array}{l}\text { Lactic acid bacteria broth enriched } \\
\text { with Eruca sativa (Rocket) extract } \\
\text { from seeds }\end{array}$ & $\begin{array}{l}\text { Pathogen-induced intestinal } \\
\text { inflammation (CXCL8) and barrier } \\
\text { dysfunction }\end{array}$ & $\begin{array}{l}\text { Caco-2 cells infected with } \\
\text { Escherichia coli }\end{array}$ & $\begin{array}{l}\text { Bonvicini } \\
\text { et al. } \\
(2020)\end{array}$ \\
\hline GLs-rich diet & $\begin{array}{l}\text { Up-regulation of the expression of } \\
\text { typical Nrf2 target genes like Nqo1, } \\
\text { Gstm1, Srxn1, and GPx } 2 \text { in the } \\
\text { colon }\end{array}$ & $\begin{array}{l}\text { Mice with inflammatory damage and } \\
\text { tumour genesis }\end{array}$ & $\begin{array}{l}\text { Lippmann } \\
\text { et al. } \\
\text { (2014) }\end{array}$ \\
\hline $\begin{array}{l}\text { 3,3'-Diindolylmethane, } \\
\text { GL naturally occurring } \\
\text { in Brassicaceae }\end{array}$ & Anti-inflammatory properties & $\begin{array}{l}\text { Adipocytes co-cultured with } \\
\text { macrophages }\end{array}$ & $\begin{array}{l}\text { Lopez- } \\
\text { Vazquez } \\
\text { et al. } \\
\text { (2017) }\end{array}$ \\
\hline $\begin{array}{l}\text { Phenethyl ITC, } \\
\text { hydrolysis product of gluconasturtiin }\end{array}$ & Anti-inflammatory properties & Psoriasis-like skin lesions in mice & $\begin{array}{l}\text { Lee et al. } \\
\text { (2011) }\end{array}$ \\
\hline \multirow[t]{2}{*}{ Allicin } & $\begin{array}{l}\text { Improvement of the colonic } \\
\text { histopathological score with a } \\
\text { reduction of IL-1b and TNF-a }\end{array}$ & Rats with colitis & \multirow[t]{2}{*}{$\begin{array}{l}\text { Li et al. } \\
(2015)\end{array}$} \\
\hline & $\begin{array}{l}\text { Block of the activation of p-38 and } \\
\text { JNK pathway }\end{array}$ & Caco- 2 cells stimulated by IL- 1 b & \\
\hline Sinigrin & $\begin{array}{l}\text { Suppression of NF- } \kappa \mathrm{B} / \mathrm{MAPK} \\
\text { pathways } \\
\text { Block of NLRP3 inflammasome } \\
\text { activation }\end{array}$ & Macrophages & $\begin{array}{l}\text { Lee et al. } \\
\text { (2017) }\end{array}$ \\
\hline Allyl nitrile & $\begin{array}{l}\text { Upregulation of antioxidant/phase II } \\
\text { enzymes in various tissues }\end{array}$ & & $\begin{array}{l}\text { Tanii } \\
\quad(2017 a, b)\end{array}$ \\
\hline Sulforaphane-rich broccoli sprouts & $\begin{array}{l}\text { Nrf2-dependent antioxidant and anti- } \\
\text { inflammatory protection }\end{array}$ & $\begin{array}{l}\text { C57BL/6 female mice infected with } \\
\text { H. pylori }\end{array}$ & $\begin{array}{l}\text { Yanaka et al. } \\
\text { (2009) }\end{array}$ \\
\hline
\end{tabular}


Table 1 continued

\begin{tabular}{llcc}
\hline Source of GLs & Effects & Subjects & References \\
\hline $\begin{array}{l}\text { Sulforaphane-rich broccoli sprouts } \\
\text { juice }\end{array}$ & $\begin{array}{l}\text { Increased trans-epithelial electrical } \\
\text { resistance, a parameter reflecting } \\
\text { the functionality of the tight } \\
\text { junctions and the integrity of the }\end{array}$ & $\begin{array}{c}\text { In vitro model of inflamed human } \\
\text { intestinal epithelium }\end{array}$ & Ferruzza \\
& cell monolayer & & et al. \\
& & & \\
\hline
\end{tabular}

their hydrolytic products, glucoraphanin, sulforaphane, moringin, phenethyl ITC, 6-(methylsulfinyl) hexyl ITC, and erucin (Jaafaru et al. 2018) showed interesting properties as modulators of oxidative stress, inflammation, and apoptosis, resulting in neuroprotective effects in different animal models (Table 2).

The most studied ITCs in neurodegenerative diseases are sulforaphane and moringin (4-( $\alpha$-1-rhamnosyloxy)-benzyl ITC), derived from the hydrolysis of the GLs glucoraphanin and glucomoringin, which showed neuroprotective activity in preclinical models of neurodegeneration due to their capacity to modulate neuronal functions (Dinkova-Kostova and Kostov 2012; Tarozzi et al. 2013).

The neuroprotective effects mediated by ITCs have been mainly attributed to Nrf2/ARE pathway positive modulation (Mein et al. 2012). Nevertheless, several recent studies reported multiple other mechanisms, including inhibition of cytochrome P450 enzymes, induction of apoptosis and cell cycle arrest, and antiinflammatory effects. These mechanisms have been proposed to work synergistically to provide the observed neuroprotective effects of ITCs (Giacoppo et al. 2015b).

In several studies carried out in vivo and in vitro on models of nervous system diseases, the treatment with GLs and ITCs have been reported to modulate the activity not only of neurons but also of glial cells, mainly astrocytes and microglia (Galuppo et al. 2013; Latronico et al. 2021; Venditti and Bianco 2020). Glial cells are resident in the periphery as well as in the central nervous system accompanying the path of pain signaling. Noteworthy, it has been demonstrated that these cells play a key role in chronic pain pathophysiology, irrespective to their location ( $\mathrm{Ji}$ et al. 2013; Lucarini et al. 2020, 2021b; Milligan and Watkins 2009). In the periphery, also enteric glia is emerging as a key regulator of visceral sensitivity (Lucarini et al. 2021b; Morales-Soto and Gulbransen 2019). Although the effect of GLs and ITCs on enteric nervous system has not been investigated yet, the dietary intake of these phytochemicals might improve gastrointestinal sensory functions, like pain, by modulating glia activation. Indeed, we cannot exclude that GLs and ITCs might act via a yet undiscovered pathway to influence pain signalling and protect neuronal functions.

GLs and $\mathrm{H}_{2} \mathrm{~S}$-releasing properties

In the last years great importance has been attributed to the hydrogen sulfide $\left(\mathrm{H}_{2} \mathrm{~S}\right)$ releasing capacity of GLs-derived natural and synthetic ITCs (Lucarini et al. 2018b; Mannelli et al. 2017; Martelli et al. 2020b). As a gas transmitter, $\mathrm{H}_{2} \mathrm{~S}$, freely crosses cell membranes and interact with different cellular and molecular targets by three main mechanisms: interaction with metal center scavenging of reactive oxygen species and reactive nitrogen species, or proteins S-persulfidation (Filipovic 2015; Ono et al. 2014; Pietri et al. 2011; Spassov et al. 2017).

$\mathrm{H}_{2} \mathrm{~S}$ is endowed of important physiological functions in the cardiovascular system as well as in nervous system, which fuelled the scientific community interest in the possibility to exploit $\mathrm{H}_{2} \mathrm{~S}$ for therapeutic purposes (Xiao et al. 2018). Nevertheless, $\mathrm{H}_{2} \mathrm{~S}$ is difficult to directly handle because it is a toxic and flammable gas. This problem pushed the research to the identification of moieties that would allow to control the dose, duration, timing, and site of $\mathrm{H}_{2} \mathrm{~S}$ release (Martelli et al. 2020b). Among them, the ITC moiety is one of the most promising. Notably, a close overlap between numerous biological effects (antioxidant, anti-inflammatory, potassium channels activity 
Table 2 Neuroprotective effects of the sources of GLs and ITCs

\begin{tabular}{|c|c|c|c|}
\hline Source of GLs & Effects & Subjects & References \\
\hline $\begin{array}{l}\text { RS-glucoraphanin } \\
\text { bioactivated with } \\
\text { myrosinase }\end{array}$ & $\begin{array}{l}\text { Decreased nuclear factor (NF)-kB translocation, pro- } \\
\text { inflammatory cytokine (IL-1 } \beta \text { ) production, and } \\
\text { apoptosis (Bax and caspase } 3 \text { expression) }\end{array}$ & $\begin{array}{l}\text { Mouse model of multiple } \\
\text { sclerosis (EAE) }\end{array}$ & $\begin{array}{l}\text { Giacoppo et al. } \\
\text { (2013) }\end{array}$ \\
\hline $\begin{array}{l}\text { RS-glucoraphanin } \\
\text { bioactivated with } \\
\text { myrosinase }\end{array}$ & $\begin{array}{l}\text { Reduced inducible nitric oxide synthase expression } \\
\text { (iNOS), intercellular adhesion molecule } 1 \text { (ICAM- } \\
\text { 1), nuclear factor (NF)-kB translocation and } \\
\text { apoptotic pathway triggering }\end{array}$ & $\begin{array}{l}\text { Rat model of cerebral ischemia/ } \\
\text { reperfusion injury }\end{array}$ & $\begin{array}{l}\text { Giacoppo et al. } \\
(2014 b)\end{array}$ \\
\hline RS-glucoraphanin & Decreased histological damage & Mouse model of spinal cord & Galuppo et al. \\
\hline $\begin{array}{l}\text { bioactivated with } \\
\text { myrosinase }\end{array}$ & Decreased astrocytes (GFAP-positive cells) activation & injury & (2013) \\
\hline RS- glucoraphanin & $\begin{array}{l}\text { Counteraction of Blood Brain Barrier alteration by } \\
\text { preserving tight junctions integrity }\end{array}$ & $\begin{array}{l}\text { Mouse model of multiple } \\
\text { sclerosis (EAE) }\end{array}$ & $\begin{array}{l}\text { Giacoppo et al. } \\
\text { (2014a) }\end{array}$ \\
\hline $\begin{array}{l}\text { Sulforaphane and } \\
\text { glucoraphanin } \\
\text { containing- food }\end{array}$ & Prevention of depression-like phenotype development & $\begin{array}{l}\text { Rat undergoing repeated social } \\
\text { defeat stress }\end{array}$ & $\begin{array}{l}\text { Yao et al. } \\
\text { (2016) }\end{array}$ \\
\hline \multirow{2}{*}{$\begin{array}{l}\text { 2-Phenethyl ITC } \\
\text { and sulforaphane }\end{array}$} & Reduced ROS production induced by $\mathrm{H}_{2} \mathrm{O}_{2}$ & \multirow{2}{*}{$\begin{array}{l}\text { Primary cultures of rat } \\
\text { astrocytes }\end{array}$} & \multirow{2}{*}{$\begin{array}{l}\text { Latronico et al. } \\
\text { (2021) }\end{array}$} \\
\hline & $\begin{array}{l}\text { Inhibition of MMP- } 2 \text { and MMP-9 expression and } \\
\text { activity induced by LPS. Inhibition of ERK activity }\end{array}$ & & \\
\hline Sulforaphane & Reduced ROS formation & $\begin{array}{l}\text { SH-SY5Y cells treated with } \\
\text { 6-OHDA }\end{array}$ & $\begin{array}{l}\text { Tarozzi et al. } \\
\text { (2013) }\end{array}$ \\
\hline Sulforaphane & Activation of ERK1/2 and Nrf-2 pathway & $\begin{array}{l}\text { 5-S-cysteinyl-dopamine- } \\
\text { induced toxicity in cortical } \\
\text { neurons }\end{array}$ & $\begin{array}{l}\text { Vauzour et al. } \\
\text { (2010) }\end{array}$ \\
\hline \multirow[t]{4}{*}{ Sulforaphane } & $\begin{array}{l}\text { Improvement of motor nerve conduction velocity, } \\
\text { nerve blood flow, and pain }\end{array}$ & \multirow[t]{4}{*}{$\begin{array}{l}\text { Neuro2a cells and sciatic nerve } \\
\text { of diabetic animals }\end{array}$} & \multirow[t]{4}{*}{$\begin{array}{l}\text { Negi et al. } \\
\text { (2011) }\end{array}$} \\
\hline & Increased expression of $\mathrm{Nrf} 2$ & & \\
\hline & Lowered NF- $\kappa \mathrm{B}$ expression and IKK phosphorylation & & \\
\hline & $\begin{array}{l}\text { Abrogation of (iNOS) and COX-2 expression. } \\
\text { Reduced TNF- } \alpha \text { and IL- } 6 \text { levels }\end{array}$ & & \\
\hline Sulforaphane & $\begin{array}{l}\text { Enhanced aquaporin- } 4 \text { expression and decreases } \\
\text { cerebral oedema }\end{array}$ & $\begin{array}{l}\text { Rodent model of traumatic } \\
\text { brain injury }\end{array}$ & $\begin{array}{l}\text { Dash et al. } \\
\text { (2009, Zhao } \\
\text { et al. (2005a) }\end{array}$ \\
\hline Sulforaphane & Protection of retinal function & Retinal ischemic injury & $\begin{array}{l}\text { Ambrecht et al. } \\
\text { (2015) }\end{array}$ \\
\hline Sulforaphane & $\begin{array}{l}\text { Reduced number of apoptotic cells in the retina } \\
\text { epithelial cell layer, enlarged a- and b-wave } \\
\text { amplitudes and delayed photoreceptor degeneration }\end{array}$ & $\begin{array}{l}\text { Light-induced damage of the } \\
\text { retina }\end{array}$ & $\begin{array}{l}\text { Kong et al. } \\
\text { (2007), Tanito } \\
\text { et al. (2005) }\end{array}$ \\
\hline \multirow[t]{3}{*}{ Sulforaphane } & $\begin{array}{l}\text { Augmented levels of heme oxygenase } 1 \text { and reduced } \\
\text { density of microglial cells in the hippocampus }\end{array}$ & \multirow{2}{*}{$\begin{array}{l}\text { Mice model of } \\
\text { neuroinflammation induced } \\
\text { by LPS }\end{array}$} & \multirow[t]{3}{*}{$\begin{array}{l}\text { Innamorato } \\
\text { et al. (2008) }\end{array}$} \\
\hline & Attenuated production of iNOS, IL- 6 , and TNF- $\alpha$ & & \\
\hline & $\begin{array}{l}\text { Nrf2-dependent induction of the phase II antioxidant } \\
\text { enzyme heme oxygenase- } 1\end{array}$ & BV2 microglial cell line & \\
\hline \multirow[t]{2}{*}{ Sulforaphane } & $\begin{array}{l}\text { Protection of nigral dopaminergic neurons against cell } \\
\text { death }\end{array}$ & \multirow[t]{2}{*}{$\begin{array}{l}\text { MPTP mouse model of } \\
\text { Parkinson's disease }\end{array}$} & \multirow[t]{2}{*}{$\begin{array}{l}\text { Jazwa et al. } \\
\text { (2011) }\end{array}$} \\
\hline & $\begin{array}{l}\text { Reduction of astrocytes and microglia activation and } \\
\text { decrease of proinflammatory mediators release in } \\
\text { basal ganglia }\end{array}$ & & \\
\hline
\end{tabular}


Table 2 continued

\begin{tabular}{|c|c|c|c|}
\hline Source of GLs & Effects & Subjects & References \\
\hline Nano-Sulforaphane & $\begin{array}{l}\text { Prevention of developmental defects of nervous } \\
\text { system induced by PhIP, heterocyclic aromatic } \\
\text { amines (HAA) formed by cooking meat at high } \\
\text { temperatures }\end{array}$ & Animal embryonies & $\begin{array}{l}\text { Zhang et al. } \\
\text { (2021) }\end{array}$ \\
\hline $\begin{array}{l}\text { 4( } \alpha \text {-l-rhamnosyloxy)- } \\
\text { benzyl ITC } \\
\text { (glucomoringin ITC) }\end{array}$ & $\begin{array}{l}\text { Regulation of reticular fibers distribution in } \\
\text { connective tissue, nuclear factor (NF)- } \kappa \mathrm{B} \\
\text { translocation, I } \mathrm{B}-\alpha \text { degradation, expression of } \\
\text { iNOS, and apoptosis }\end{array}$ & $\begin{array}{l}\text { Mouse model of spinal cord } \\
\text { injury }\end{array}$ & $\begin{array}{l}\text { Giacoppo et al. } \\
\text { (2015a) }\end{array}$ \\
\hline $\begin{array}{l}\text { 4( } \alpha \text {-L-rhamnosyloxy)- } \\
\text { benzyl ITC }\end{array}$ &  & $\begin{array}{l}\text { Rat model of cerebral ischemia/ } \\
\text { reperfusion damage }\end{array}$ & $\begin{array}{l}\text { Galuppo et al. } \\
\text { (2015) }\end{array}$ \\
\hline (Glucomoringin ITC) & $\begin{array}{l}\text { Decreased markers of inflammation (phospho-ERK } \\
\text { p42/44, p-selectin) and oxidative stress (inducible } \\
\text { Nitric Oxide Synthase (iNOS), MMP-9) }\end{array}$ & & \\
\hline $\begin{array}{l}\text { 4( } \alpha \text {-L-rhamnosyloxy)- } \\
\text { benzyl ITC } \\
\text { (glucomoringin ITC) }\end{array}$ & Potent anti-inflammatory activity & $\begin{array}{l}\text { Murine Subacute Parkinson's } \\
\text { Disease }\end{array}$ & $\begin{array}{l}\text { Giacoppo et al. } \\
\text { (2017b) }\end{array}$ \\
\hline $\begin{array}{l}\text { Allyl-ITC (In lower } \\
\text { micromolar range) }\end{array}$ & $\begin{array}{l}\text { Reduced NF- } \mathrm{KB} \text { expression } \\
\text { Inhibition of } \mathrm{c} \text {-Jun N-terminal kinase }\end{array}$ & $\begin{array}{l}\text { Murine microglial cells treated } \\
\text { with LPS }\end{array}$ & $\begin{array}{l}\text { Subedi et al. } \\
\text { (2017) }\end{array}$ \\
\hline $\begin{array}{l}\text { Eruca sativa seed } \\
\text { extract }\end{array}$ & $\begin{array}{l}\text { Reduced apoptosis and production of pro- } \\
\text { inflammatory cytokines } \\
\text { Reduced COX } 2 \text { and TLR4/NLRP3 inflammasome } \\
\text { expression } \\
\text { Restauration of interleukin } 10 \text { expression }\end{array}$ & $\begin{array}{l}\text { NSC-34 motor neurons treated } \\
\text { with the medium of LPS- } \\
\text { treated RAW } 264.7\end{array}$ & $\begin{array}{l}\text { Gugliandolo } \\
\text { et al. (2018) }\end{array}$ \\
\hline
\end{tabular}

modulation and chemoprevention) attributed to natural ITCs and those of the gas transmitter $\mathrm{H}_{2} \mathrm{~S}$ can be clearly observed (Martelli et al. 2020b). Naturally occurring $\mathrm{H}_{2} \mathrm{~S}$ donors, like ITCs, are widely investigated since their safety profile is usually greater than many synthetic donors. The limitations to their use can be the structurally amenability to chemical transformations (e.g., during the isolation of these compounds from the plants), the poor water solubility, and the generation of by-products after $\mathrm{H}_{2} \mathrm{~S}$ release. Thus, in recent years, ITCs have been used as scaffold for the synthesis of new stable compounds or have been combined with other drugs to obtain multitarget molecules with improved anti-inflammatory, antioxidant, and neuroprotective effects (Sestito et al. 2019).

In the context of pain pharmacology, it is important to point out the dual role of $\mathrm{H}_{2} \mathrm{~S}$, which essentially depend upon the doses: a low dose contributes to reduce pain, while a high dose elicits pain. Consistently, it has been observed that, by employing slow releasing $\mathrm{H}_{2} \mathrm{~S}$ agents or low dose of $\mathrm{H}_{2} \mathrm{~S}$, attenuation of pain can be achieved. Several mechanisms account for this pharmacological effect of $\mathrm{H}_{2} \mathrm{~S}$, such as the reduction of inflammation, CGRP and oxidative stress (Guo et al. 2020), as well as the activation of KATP and Kv7 channels (Mannelli et al. 2017; Martelli et al. 2013). Indeed, Kv7 voltage-gated potassium channel subunits have been demonstrated to be responsible for most of the $\mathrm{H}_{2} \mathrm{~S}$-mediated effects of ITCs (Martelli et al. 2014; Schleifenbaum et al. 2010). Selectively blocking Kv7 channels with XE-991 (Wang et al. 1998) has been shown to cause primary sensory neurons hyperexcitability (Zhang et al. 2019). Accordingly, the activation of Kv7 channels (Miceli et al. 2008) exerted neuroprotective effects against chemotherapy-induced neuropathy (Abd-Elsayed et al. 2015; Nodera et al. 2011) and decreased osteoarticular and neuropathic pain (Brown and Passmore 2009; Li et al. 2008a). In 2018, Di Cesare Mannelli et al. reported that XE991 pre-treatment fully counteracted the pain-relieving effects of ITCs and NaHS, administered by either the systemic or intracerebroventricular route, in a mouse model of oxaliplatin-induced neuropathy. Accordingly, 
electrophysiological in vitro experiments revealed that $\mathrm{Kv} 7.2 / 3$ heteromeric currents, involved in the regulation of pain transmission through the spinothalamic pathway (Wang et al. 1998), can be concentrationdependently activated by $\mathrm{H}_{2} \mathrm{~S}$-releasing ITCs. In the same animal model of neuropathy, the dose-dependent rise of pain threshold mediated by both glucoraphanin (GL) and sulforaphane (ITC) was fully prevented by the simultaneous administration of haemoglobin and XE991(Lucarini et al. 2018b). Likewise, in a model of diabetic neuropathy induced by streptozotocin, the administration of a bio-activated Eruca sativa defatted meal or its main GL, glucoerucin, caused a dose-dependent pain-relief dependent upon $\mathrm{H}_{2} \mathrm{~S}$ release and $\mathrm{Kv} 7$ activation (Lucarini et al. 2019b). Kv7 channel thus emerged as the main targets responsible for the antinociceptive activity of GLs and ITCs.

$\mathrm{H}_{2} \mathrm{~S}$ pronociceptive effect, which occurs in the case of a massive bioavailability of this gas transmitter, seems instead mediated by the positive modulation of T-type calcium channels, voltage-gated sodium channels, as well as TRPA1, TRPV1 and TRPC6 channels, the upregulation of spinal NMDA receptors and the sensitization of purinergic receptors (Guo et al. 2020). A series of mechanisms which are likely less sensitive to $\mathrm{H}_{2} \mathrm{~S}$, needing a great stimulus to be activated. The bell-shaped dose-dependence showed by ITCs (Mannelli et al. 2017) likely reflect the complex pharmacokinetics and pharmacodynamics of $\mathrm{H}_{2} \mathrm{~S}$-releasing molecules (Ahmad et al. 2016; Szabo et al. 2014).

Slow $\mathrm{H}_{2} \mathrm{~S}$-donors, long-lasting generating low concentrations of $\mathrm{H}_{2} \mathrm{~S}$, such as GYY4137, are preferred choice in the treatment of disorders like chronic pain ( $\mathrm{Li}$ et al. 2008b). GLs, being hydrolysable in vivo (Fahey et al. 2015, 2019), can be assimilated to a slow $\mathrm{H}_{2} \mathrm{~S}$-donor and effectively employed for pain management. Indeed, though ITCs are considered responsible for the pain relief, GLs show a better kinetic profile since they are usually more stable than ITCs, especially in solution (Fahey et al. 2017), while in vivo they can mediate a slow release of ITCs and consequently an even slower and longer release of $\mathrm{H}_{2} \mathrm{~S}$. Although the role played by $\mathrm{H}_{2} \mathrm{~S}$ in the acute antinociceptive effect of GLs and ITCs appear to be clear, the involvement of $\mathrm{H}_{2} \mathrm{~S}$ in the neuroprotective efficacy of these phytochemicals has not been ascertained yet. Anyway, sulphur-containing natural compounds, proved to be neuroprotective because of their direct and indirect anti-inflammatory and antioxidant properties, including the scavenging of radicals, the down-regulation of microglial-derived inflammatory mediators and cytotrophic effects in astrocytes (Venditti and Bianco 2020). Altogether these findings support the hypothesis that a controlled release of $\mathrm{H}_{2} \mathrm{~S}$ can contribute also to the neuroprotective efficacy showed by GLs and ITCs against chronic pain.

Other possible mechanisms involved in GLsmediated anti-hyperalgesic effects

Increasing evidence attested the effectiveness of GLs and ITCs intake in preventing cognitive deficits induced by chemical agents, such as phencyclidine (Shirai et al. 2015), by traumatic brain injury or by stressful stimuli (Zhao et al. 2005b). In a mouse model of irritable bowel syndrome, the administration of an extract of Camelina sativa var. Madalina defatted seeds, rich in sinapine, GLs, and flavonol glycosides, resulted able to counteract oxidative stress in both brain and bowel tissues, as well as the concomitant behavioural alterations (Cojocariu et al. 2020). Sulforaphane, the ITC derived from glucoraphanin, has been reported to be able to counteract the damage caused by traumatic brain injury and enhanching cell survival by simultaneously reducing lipid peroxidation, decreasing blood brain barrier permeability, and increasing the expression of aquaporin 4 channels (Dash et al. 2009; Sajja et al. 2018; Zhao et al. 2005c). The latter effect appears particularly interesting in the context of glymphatic system, highly active during sleep, which is responsible for clearing away waste from the brain and essential for maintaining brain immune homeostasis across the lifespan (Eugene and Masiak 2015; Plog and Nedergaard 2018). A recent review suggested GLs and the potential modulation of aquaporins activity as new approach to improve the quality of life in women suffering from endometriosis (García-Ibañez et al. 2020). Thus, though the role of aquaporins in pain need to be further investigated, the positive effect of ITCs on aquaporins might empower their anti-inflammatory and neuroprotective profile, strengthening the rational of their use for chronic pain management.

Yet, recently, cGMP-dependent protein kinase I, already known to contribute to $\mathrm{H}_{2} \mathrm{~S}$-mediated vasorelaxation (Bucci et al. 2012) and localized also in nociceptors, was found to be critically involved in the 
mechanisms of central sensitization and neuropathic pain establishment (Wang et al. 2021). Albeit preliminary, these observations pave the way for new studies aimed at understanding if cGMP system modulation might be another hidden mechanisms behind the beneficial effects of natural occurring $\mathrm{H}_{2} \mathrm{~S}$ donors, like GLs, on pain.

Finally, it is important to mention the role played by GLs and ITCs in the maintaing of intestinal microbial homeostasis. Indeed, GLs can be metabolised in vivo into ITCs by members of the human gut microbiome that regulate host epigenetics ( $\mathrm{Li}$ et al. 2011; Shock et al. 2021). Vice versa, these phytochemicals are active modifiers of gut microbial communities (Dingeo et al. 2020; Kaczmarek et al. 2019b). Broccoli consumption in humans has been shown to increase intestinal Firmicutes and decrease of Bacteroidetes, respectively (Kaczmarek et al. 2019a). These bacterial phyla togheter represent more than $90 \%$ of the total gut microbiota (Qin et al. 2010) and the alteration of Firmicutes/Bacteroidetes ratio, has been associated with several pathologic conditions (Guo et al. 2019; Li et al. 2020; Minerbi et al. 2019b; Pittayanon et al. 2019; Zeber-Lubecka et al. 2016). At the same time, human gut microbiota conditionated by a Brassicaceae enriched diet contributes to increase GLs bioavailability (Sikorska-Zimny and Beneduce 2020). GLs hydrolysis products, like sulforaphane and benzyl ITC, have significant antimicrobial activity against Gram-positive and Gram-negative bacteria isolated from the human intestinal tract, and might help in preventing pathoges overgrowth once administered in patients (Aires et al. 2009). Moreover, in vitro it has been observed that broccoli leachate media can favour the growth of lactic acid bacteria, which implies an increased production of lactate and short-chain fatty acids, demonstrating a prebiotic effect for GLs and ITCs (Kellingray et al. 2021). Interestingly, intestinal dysbiosis co-occurs with the development of several painful diseases. Among them there are either gastrointestinal disorders, namely irritable bowel syndrome (IBS) and inflammatory bowel diseases (IBDs), or extra-intestinal diseases such as fibromyalgia, metabolic syndrome, rheumatic diseases, allergic and atopic disease, and neuropsychiatric disorders (D'Amato et al. 2020; Defaye et al. 2020). Accordingly, gut microbiota has been reported to regulates not only visceral sensitivity, but also musculoskeletal and neuropathic pain (Boer et al. 2019; Dekker Nitert et al. 2020; Ding et al. 2021; Minerbi et al. 2019a). Considering that changes in the composition and metabolism of microbiota almost inevitably cause alterations in the mechanisms mediating pain signalling (Lucarini et al. 2021a; O'Mahony et al. 2017; Pusceddu and Gareau 2018), the role played by GLs and ITCs in maintaining the microbial homeostasis might represent an additional mechanism in the regulation of pain disorders.

\section{GLs bioavailability}

The bioavailability of GLs or their active metabolites depends on several parameters grouped as follows: (1) the concentration of GLs in the plant; (2) the conditions of storage and processing of the raw material and the stability of myrosinase; (3) GLs and derivatives peculiar physico-chemical properties; 4) gastrointestinal transit and microbiota fermentation (Banerjee et al. 2014; Fernández-León et al. 2017; Holst and Williamson 2004a; Jones et al. 2006).

GLs and ITCs found in Brassica-vegetables are subject to a variety of changes during food processing and the analysis of degradation products is often challenging (Barba et al. 2016). During the fermentation, commonly used for white cabbage in Germany ("Sauerkraut"), the major breakdown products are aliphatic ITCs, and ascorbigen (Hanschen et al. 2014). In general, thermal degradation leads to the transformation of GLs predominantly to nitriles through several chemical mechanisms. ITCs are instead severely affected by thermal treatment, and decompose further to a variety of volatile and non-volatile compounds. Anyway, GLs can be differently degraded according to the heat treatment which is employed. For example, mild heat treatment inactivates the epithiospecifier protein, without altering myrosinase activity, thus increasing ITCs formation (Jones et al. 2010). Longer or high temperature $\left(80^{\circ} \mathrm{C}\right)$ heat treatment also inactivate myrosinase, (Björkman and Lönnerdal 1973; Ghawi et al. 2012), resulting in a higher content of GLs and a consequent decrease amount of free ITCs (Barba et al. 2016). Boiling can severely affect the levels of GLs (Nugrahedi et al. 2015; Verkerk et al. 2009), causing GLs losses of $5-75 \%$, varying as a function of each GL structure (indole GLs are thermally less stable than aliphatic ones) (Hanschen et al. 2012) and the context in which it is found. Indeed, besides heat, several other 
conditions, such as $\mathrm{pH}$ value, plant matrix, $\mathrm{Fe}^{2+}$ ions, vitamin $\mathrm{C}$, other antioxidants, or the water content, strongly affect the susceptibility and the pathway of the reaction, leading to a wide range of metabolites, whom biological activities are mostly unknown (Hanschen et al. 2014). Hence, the evaluation of the most appropriate cooking method should be considered an important factor to preserve the beneficial effects of Brassicaceae, which are mainly due to GLs and ITCs content (Baenas et al. 2019).

When raw cruciferous are consumed, GLs are hydrolysed by myrosinase in the upper gastrointestinal tract to different metabolites (ITCs, nitriles, oxazolidine-2-thiones, and indole-3-carbinols) while, when cooked cruciferous are ingested, GLs can transit to the colon where they are hydrolysed by the resident microflora (Dinkova-Kostova and Kostov 2012). At this level, based on inter-individual microbial diversity, a wide range of metabolites can be generated (Barba et al. 2016). Interestingly, the frequent intake of Brassica sp. vegetables favours the growth of GLshydrolysing bacteria within the gut (Angelino and Jeffery 2014). Although the largest fraction of GLs is metabolized in the gut lumen after ingestion, their absorption mostly occur in the small intestine, where, a percentage is absorbed by the epithelium (Angelino and Jeffery 2014). Although several studies demonstrated that GLs can be absorbed in their intact form, few research were carried out to study the absorption mechanism of intact GLs and the fate of their major degradation products (Budnowski et al. 2015). Overall considering their chemical features, unmodified GLs can scarcely reach the human tissues, whereas their breakdown products, such as ITCs, are more easily distributed throughout the body (Holst and Williamson 2004b), since they can cross the intestinal epithelial barrier by passive diffusion. After they are absorbed, GLs metabolites can have very different fates, they can be metabolized further in the enterocyte or secreted back into the gut lumen, alternatively, they can pass into the plasma (Angelino and Jeffery 2014). Before passing into the plasma, ITC can be also conjugate with the thiol group of the glutathione system. The resulting GSH-ITC conjugate can disassociate again at low glutathione plasma concentration or get enzymatically cleaved to release the free, and biologically active ITC (Shakour et al. 2021) which can passively cross cell membranes either as free compounds or as cysteine-bound derivatives (Holst and Williamson 2004b). Ye et al. demonstrated that broccoli sprouts-contained ITCs are quickly distributed in the organism, from which they are eliminated following a first-order kinetics (Holst and Williamson 2004b; Ye et al. 2002). These chemical and pharmacokinetic properties, combined with evidence about the acute pain relief mediated by GLs and ITCs (effect peaking between 15 and $45 \mathrm{~min}$ ), indicates that through the systemic blood circuit most of the ingested ITCs can adequately reach the different districts sites of pain regulation in the body where they can exert their beneficial effects. Moreover, the abovementioned binding to plasmatic GSH might contribute to the slow and sustained release of ITCs, and consequently $\mathrm{H}_{2} \mathrm{~S}$, at the target sites, supporting their protective effects on tissue physiology.

Other important discriminants in compounds bioavailability are the inter-individual variability which can occur in the response to the xenobiotics (Cartea and Velasco 2008) and the peculiar features of the GLs employed. For instance, the activity of GLs-metabolizing microbiota can vary a lot from individual to individual and not all the glucosynolates can be effectively hydrolysed by the same gut bacteria (Lucarini et al. 2018b, 2019a). It is thus clear the importance to guarantee an adequate intake of these phytochemicals by a correct manipulation of raw materials and an optimized formulation of final preparations.

\section{GLs-analgesic drugs interactions}

Little is known about the positive or negative relationships occurring between GLs, their metabolites, and analgesic drugs, though it is an important aspect to consider when developing therapeutic plans. ITCs can potentially interfere with the pharmacokinetics of several molecules which are substrate of the ATP-binding cassette transporters, including most multidrug resistance proteins (Telang et al. 2009). Sulforaphane can also compete with the metabolism of other drugs, since it is a substrate of phases I, II, III enzymes. Moreover, sulforaphane turned out to be a potent inducer of phase II enzymes and regulator of cytochrome P-450 expression and function (Zhou et al. 2007). These mechanisms support the preventive effects which were attributed to this natural ITC in degenerative diseases. On the other hand, the modification of the above-mentioned detoxification 
systems might alter the bioavailability and bioactivity of concomitantly administered drugs (Fimognari et al. 2008; La Marca et al. 2012; Telang et al. 2009). The in vivo pharmacodynamic interactions between GLs and other analgesic drugs are almost unknown. Allyl-ITC has been reported to prevent the hepatotoxic effects caused by acetaminophen (Kim et al. 2020; Lim et al. 2015), while sulforaphane resulted able to improve H. pylori- and NSAID-induced gastrointestinal symptoms in mice and humans (Yanaka 2017; Yanaka et al. 2009). Likewise, also nonsteroidal antiinflammatory drugs formulated to release $\mathrm{H}_{2} \mathrm{~S}$ in vivo demonstrated to be less gastro-harmful than the parent drugs due to the positive effects showed by this gaseous mediator on the gastrointestinal tract (Dief et al. 2015; Fiorucci et al. 2007).

Noteworthy, sulforaphane can cause an augmented expression of opioid- $\mu$ receptor (Wang and Wang 2017), enhancing morphine analgesic efficacy (Ferreira-Chamorro et al. 2018; Fu et al. 2021; Redondo et al. 2017) and therefore reducing the dose required to maintain the analgesic effect during long-term therapies. Moreover, $\mathrm{H}_{2} \mathrm{~S}$ released by ITCs has been reported to inhibit opioid withdrawal-induced pain sensitization and to attenuate opioid dependence (Yang et al. 2014a, b).

Although the positive or negative implications of administering GLs together with other drugs need to be further investigated, the association with GLs might not only empower the efficacy of classical analgesics, but also prevent some of their side effects, improving the adherence of patients to the therapy.

\section{GLs toxicity}

Ruminants and horses which ingested high levels of allyl-ITC displayed an irritation of the gastrointestinal mucosa accompanied by abdominal pain and cramps (Taljaard 1993). Anaemia is another possible adverse effect resulting from an excessive consume of Brassicaceae (Herr and Büchler 2010). An exaggerated intake of vegetables and/or seeds from the Brassicaceae family, as well as of high doses of GLs, can affect the functioning of thyroid, liver and kidney, can reduce the growth as well as the reproductive performance, but very rarely cause death (Tripathi and Mishra 2007). Nitriles originating from an alternative metabolism of GLs instead turned out to be hepatotoxic. However, no significant or consistent abnormalities in liver and thyroid function have been observed supplementing mice diet with different sprout extracts in therapeutic quantities. Supporting GLs safety, it has been demonstrated that broccoli sprout intake ameliorates cholesterol metabolism and reduces multiple oxidative biomarkers without causing side effects (Herr and Büchler 2010).

\section{Conclusions}

The wide spectrum of benefits, accompanied by a good bioavailability and very limited side effects, gives a high degree of clinical translatability to GLs-based products. Moreover, the efficacy and versatility shown by these phytochemicals in the treatment of different painful conditions, together with the possibility of administering them as food supplements, encourages their use for the treatment of chronic pain in patients.

Acknowledgements This research was supported by the Italian Ministry of Instruction, University and Research (MIUR), and by the University of Florence.

Funding The authors have no relevant financial or nonfinancial interests to disclose.

\section{Data availability Not applicable. \\ Code availability Not applicable.}

\section{Declarations}

Conflict of interest The authors have no conflicts of interest to declare that are relevant to the content of this article.

Consent to participate Not applicable.

Consent for publication Not applicable.

Ethical approval Not applicable.

Open Access This article is licensed under a Creative Commons Attribution 4.0 International License, which permits use, sharing, adaptation, distribution and reproduction in any medium or format, as long as you give appropriate credit to the original author(s) and the source, provide a link to the Creative Commons licence, and indicate if changes were made. The images or other third party material in this article are included in the article's Creative Commons licence, unless indicated otherwise in a credit line to the material. If material is not included in the article's Creative Commons licence and your intended use is not permitted by statutory regulation or exceeds the permitted use, you will need to obtain permission directly 
from the copyright holder. To view a copy of this licence, visit http://creativecommons.org/licenses/by/4.0/.

\section{References}

Abd-Elsayed AA, Ikeda R, Jia Z, Ling J, Zuo X, Li M, Gu JG (2015) KCNQ channels in nociceptive cold-sensing trigeminal ganglion neurons as therapeutic targets for treating orofacial cold hyperalgesia. Mol Pain 11:s12990

Agerbirk N, Olsen CE (2012) Glucosinolate structures in evolution. Phytochemistry 77:16-45

Ahmad N, Malagoli M, Wirtz M, Hell R (2016) Drought stress in maize causes differential acclimation responses of glutathione and sulfur metabolism in leaves and roots. BMC Plant Biol 16:1-15

Aires A, Mota VR, Saavedra MJ, Rosa EA, Bennett RN (2009) The antimicrobial effects of glucosinolates and their respective enzymatic hydrolysis products on bacteria isolated from the human intestinal tract. J Appl Microbiol 106:2086-2095

Ambrecht LA, Perlman JI, McDonnell JF, Zhai Y, Qiao L, Bu P (2015) Protection of retinal function by sulforaphane following retinal ischemic injury. Exp Eye Res 138:66-69

Andersen HH, Vecchio SL, Gazerani P, Arendt-Nielsen L (2017) Dose-response study of topical allyl isothiocyanate (mustard oil) as a human surrogate model of pain, hyperalgesia, and neurogenic inflammation. Pain 158:1723-1732

Angelino D, Jeffery E (2014) Glucosinolate hydrolysis and bioavailability of resulting isothiocyanates: focus on glucoraphanin. J Funct Foods 7:67-76

Areti A, Yerra VG, Naidu V, Kumar A (2014) Oxidative stress and nerve damage: role in chemotherapy induced peripheral neuropathy. Redox Biol 2:289-295

Aziz Q, Giamberardino MA, Barke A, Korwisi B, Baranowski AP, Wesselmann U, Rief W, Treede R-D (2019) The IASP classification of chronic pain for ICD-11: chronic secondary visceral pain. Pain 160:69-76

Baenas N, Marhuenda J, García-Viguera C, Zafrilla P, Moreno DA (2019) Influence of cooking methods on glucosinolates and isothiocyanates content in novel cruciferous foods. Foods 8:257

Banerjee A, Variyar PS, Chatterjee S, Sharma A (2014) Effect of post harvest radiation processing and storage on the volatile oil composition and glucosinolate profile of cabbage. Food Chem 151:22-30

Barba FJ, Nikmaram N, Roohinejad S, Khelfa A, Zhu Z, Koubaa M (2016) Bioavailability of glucosinolates and their breakdown products: impact of processing. Front Nutr 3:24

Barham L (2012) Economic burden of chronic pain across Europe. J Pain Palliat Care Pharmacother 26:70-72

Bennett MI, Kaasa S, Barke A, Korwisi B, Rief W, Treede R-D (2019) The IASP classification of chronic pain for ICD-11: chronic cancer-related pain. Pain 160:38-44

Bi-Yi C, Wen-Qiao J, Jie C, Xin-Jian C, You-Cheng Z, ZhiQiang C (1999) Analgesic activity and selectivity of isothiocyanate derivatives of fentanyl analogs for opioid receptors. Life Sci 65:1589-1595
Biswas SK (2016) Does the Interdependence between Oxidative Stress and Inflammation Explain the Antioxidant Paradox? Oxid Med Cell Longev 2016:5698931

Björkman R, Lönnerdal B (1973) Studies on myrosinases III: Enzymatic properties of myrosinases from Sinapis alba and Brassica napus seeds. Biochim Biophys Acta (BBA) 327:121-131

Boer CG, Radjabzadeh D, Medina-Gomez C, Garmaeva S, Schiphof D, Arp P, Koet T, Kurilshikov A, Fu J, Ikram MA, Bierma-Zeinstra S, Uitterlinden AG, Kraaij R, Zhernakova A, van Meurs JBJ (2019) Intestinal microbiome composition and its relation to joint pain and inflammation. Nat Commun 10:4881

Bonvicini F, Pagnotta E, Punzo A, Calabria D, Simoni P, Mirasoli M, Passerini N, Bertoni S, Ugolini L, Lazzeri L, Gentilomi GA, Caliceti C, Roda A (2020) Effect of Lactobacillus acidophilus Fermented Broths Enriched with Eruca sativa Seed Extracts on Intestinal Barrier and Inflammation in a Co-Culture System of an Enterohemorrhagic Escherichia coli and Human Intestinal Cells. Nutrients 12:3064

Breivik H, Collett B, Ventafridda V, Cohen R, Gallacher D (2006) Survey of chronic pain in Europe: prevalence, impact on daily life, and treatment. Eur J Pain 10:287-333

Brown DA, Passmore GM (2009) Neural KCNQ (kv7) channels. Br J Pharmacol 156:1185-1195

Bucci M, Papapetropoulos A, Vellecco V, Zhou Z, Zaid A, Giannogonas P, Cantalupo A, Dhayade S, Karalis KP, Wang R (2012) cGMP-dependent protein kinase contributes to hydrogen sulfide-stimulated vasorelaxation. PLoS ONE 7:e53319

Budnowski J, Hanske L, Schumacher F, Glatt H, Platz S, Rohn S, Blaut M (2015) Glucosinolates are mainly absorbed intact in germfree and human microbiota-associated mice. J Agric Food Chem 63:8418-8428

Capuano E, Dekker M, Verkerk R, Oliviero T (2017) Food as pharma? The case of glucosinolates. Curr Pharm Des 23:2697-2721

Cartea ME, Velasco P (2008) Glucosinolates in Brassica foods: bioavailability in food and significance for human health. Phytochem Rev 7:213-229

Christie M (2008) Cellular neuroadaptations to chronic opioids: tolerance, withdrawal and addiction. $\mathrm{Br} \mathrm{J}$ Pharmacol 154:384-396

Citi V, Martelli A, Testai L, Marino A, Breschi MC, Calderone V (2014) Hydrogen sulfide releasing capacity of natural isothiocyanates: is it a reliable explanation for the multiple biological effects of Brassicaceae? Planta Med 80:610-613

Clemente M, Miguel MD, Felipe KB, Gribner C, Moura P, Rigoni AA, Parisotto E, Piltz M, Valdameri G, Henneberg R, Schonhofen C (2020) Biomarkers of oxidative stress and inflammation in people witha physical disability treated with a standardized extract of Nasturtium officinale: A randomized, double-blind, and placebo-controlled trial. Phytother Res 34:2756-2765

Cojocariu RO, Balmus IM, Lefter R, Hritcu L, Ababei DC, Ciobica A, Copaci S, Mot SEL, Copolovici L, Copolovici DM, Jurcoane S (2020) Camelina sativa methanolic and ethanolic extract potential in alleviating oxidative stress, memory deficits, and affective impairments in stress 
exposure-based irritable bowel syndrome mouse models. Oxid Med Cell Longev 2020:9510305

Crofford LJ (2013) Use of NSAIDs in treating patients with arthritis. Arthritis Res Ther 15(3):S2

D’Amato A, Di Cesare Mannelli L, Lucarini E, Man AL, Le Gall G, Branca JJV, Ghelardini C, Amedei A, Bertelli E, Regoli M, Pacini A, Luciani G, Gallina P, Altera A, Narbad A, Gulisano M, Hoyles L, Vauzour D, Nicoletti C (2020) Faecal microbiota transplant from aged donor mice affects spatial learning and memory via modulating hippocampal synaptic plasticity- and neurotransmission-related proteins in young recipients. Microbiome 8:140

Dahlhamer J, Lucas J, Zelaya C, Nahin R, Mackey S, DeBar L, Kerns R, Von Korff M, Porter L, Helmick C (2018) Prevalence of chronic pain and high-impact chronic pain among adults-United States, 2016. Morb Mortal Wkly Rep 67:1001

Dash PK, Zhao J, Orsi SA, Zhang M, Moore AN (2009) Sulforaphane improves cognitive function administered following traumatic brain injury. Neurosci Lett 460:103-107

Davidson RK, Jupp O, de Ferrars R, Kay CD, Culley KL, Norton R, Driscoll C, Vincent TL, Donell ST, Bao Y (2013) Sulforaphane represses matrix-degrading proteases and protects cartilage from destruction in vitro and in vivo. Arthritis Rheum 65:3130-3140

Defaye M, Gervason S, Altier C, Berthon J-Y, Ardid D, Filaire E, Carvalho FA (2020) Microbiota: a novel regulator of pain. J Neural Transm 127:445-465

Dekker Nitert M, Mousa A, Barrett H, Naderpoor N, De Courten B (2020) Altered Gut Microbiota Composition Is Associated With Back Pain in Overweight and Obese Individuals. Front Endocrinol 11:605

Dief A, Mostafa D, Sharara G, Zeitoun T (2015) Hydrogen sulfide releasing naproxen offers better anti-inflammatory and chondroprotective effect relative to naproxen in a rat model of zymosan induced arthritis. Eur Rev Med Pharmacol Sci 19:1537-1546

Ding W, You Z, Chen Q, Yang L, Doheny J, Zhou X, Li N, Wang S, Hu K, Chen L, Xia S, Wu X, Wang C, Zhang C, Chen L, Ritchie C, Huang P, Mao J, Shen S (2021) Gut microbiota influences neuropathic pain through modulating proinflammatory and anti-inflammatory T cells. Anesth Analg 132:1146-1155

Dingeo G, Brito A, Samouda H, Iddir M, La Frano MR, Bohn T (2020) Phytochemicals as modifiers of gut microbial communities. Food Funct 11:8444-8471

Dinkova-Kostova AT, Holtzclaw WD, Cole RN, Itoh K, Wakabayashi N, Katoh Y, Yamamoto M, Talalay P (2002) Direct evidence that sulfhydryl groups of Keap1 are the sensors regulating induction of phase 2 enzymes that protect against carcinogens and oxidants. Proc Natl Acad Sci 99:11908-11913

Dinkova-Kostova AT, Kostov RV (2012) Glucosinolates and isothiocyanates in health and disease. Trends Mol Med 18:337-347

Distrutti E, Cipriani S, Renga B, Mencarelli A, Migliorati M, Cianetti S, Fiorucci S (2010) Hydrogen sulphide induces $\mu$ opioid receptor-dependent analgesia in a rodent model of visceral pain. Mol Pain 6:1744-8069

Dos Santos AO, do Val, D.R., da Silveira, F.D., Gomes, F.I.F., Freitas, H.C., de Assis, E.L., de Almeida, D.K.C., da Silva,
I.I.C., Barbosa, F.G., Mafezoli, J., (2018) Antinociceptive, anti-inflammatory and toxicological evaluation of semisynthetic molecules obtained from a benzyl-isothiocyanate isolated from Moringa oleifera Lam. in a temporomandibular joint inflammatory hypernociception model in rats. Biomed Pharmacother 98:609-618

Esteve M (2020) Mechanisms underlying biological effects of cruciferous glucosinolate-derived isothiocyanates/indoles: a focus on metabolic syndrome. Front Nutr 7:111

Eugene AR, Masiak J (2015) The neuroprotective aspects of sleep. Medtube Sci 3:35

Fahey JW, Holtzclaw WD, Wehage SL, Wade KL, Stephenson KK, Talalay P (2015) Sulforaphane bioavailability from glucoraphanin-rich broccoli: Control by active endogenous myrosinase. PLoS ONE 10:e0140963

Fahey JW, Wade KL, Stephenson KK, Panjwani AA, Liu H, Cornblatt G, Cornblatt BS, Ownby SL, Fuchs E, Holtzclaw WD, Cheskin LJ (2019) Bioavailability of sulforaphane following ingestion of glucoraphanin-rich broccoli sprout and seed extracts with active myrosinase: a pilot study of the effects of proton pump inhibitor administration. Nutrients 11:1489

Fahey JW, Wade KL, Wehage SL, Holtzclaw WD, Liu H, Talalay P, Fuchs E, Stephenson KK (2017) Stabilized sulforaphane for clinical use: phytochemical delivery efficiency. Mol Nutr Food Res 61:1600766

Fernández-León AM, Fernández-León MF, González-Gómez D, Ayuso MC, Bernalte MJ (2017) Quantification and bioaccessibility of intact glucosinolates in broccoli 'Parthenon'and Savoy cabbage 'Dama.' J Food Compos Anal 61:40-46

Ferreira-Chamorro P, Redondo A, Riego G, Leánez S, Pol O (2018) Sulforaphane inhibited the nociceptive responses, anxiety-and depressive-like behaviors associated with neuropathic pain and improved the anti-allodynic effects of morphine in mice. Front Pharmacol 9:1332

Ferruzza S, Natella F, Ranaldi G, Murgia C, Rossi C, Trošt K, Mattivi F, Nardini M, Maldini M, Giusti AM, Moneta E, Scaccini C, Sambuy Y, Morelli G, Baima S (2016) Nutraceutical Improvement Increases the Protective Activity of Broccoli Sprout Juice in a Human Intestinal Cell Model of Gut Inflammation. Pharmaceuticals (basel) 9:48

Filipovic MR (2015) Persulfidation (S-sulfhydration) and H2S. Chem Biochem Pharmacol Hydrogen Sulfide 45:29-59

Fimognari C, Lenzi M, Hrelia P (2008) Interaction of the isothiocyanate sulforaphane with drug disposition and metabolism: pharmacological and toxicological implications. Curr Drug Metab 9:668-678

Fiorucci S, Santucci L, Distrutti E (2007) NSAIDs, coxibs, CINOD and H2S-releasing NSAIDs: what lies beyond the horizon. Dig Liver Dis 39:1043-1051

Fu J, Xu M, Xu L, Ni H, Zhao B, Ni C, Huang M, Zhu J, Luo G, Yao M (2021) Sulforaphane alleviates hyperalgesia and enhances analgesic potency of morphine in rats with cancer-induced bone pain. Eur J Pharmacol 909:174412

Galuppo M, Giacoppo S, De Nicola GR, Iori R, Mazzon E, Bramanti P (2013) RS-Glucoraphanin bioactivated with myrosinase treatment counteracts proinflammatory cascade and apoptosis associated to spinal cord injury in an experimental mouse model. J Neurol Sci 334:88-96 
Galuppo M, Giacoppo S, Iori R, De Nicola GR, Milardi D, Bramanti P, Mazzon E (2015) 4( $\alpha$-L-rhamnosyloxy)-benzyl isothiocyanate, a bioactive phytochemical that defends cerebral tissue and prevents severe damage induced by focal ischemia/reperfusion. J Biol Regul Homeost Agents 29:343-356

García-Ibañez P, Yepes-Molina L, Ruiz-Alcaraz AJ, MartínezEsparza M, Moreno DA, Carvajal M, García-Peñarrubia P (2020) Brassica bioactives could ameliorate the chronic inflammatory condition of endometriosis. Int J Mol Sci 21:9397

Gaskin DJ, Richard P (2012) The economic costs of pain in the United States. J Pain 13:715-724

Ghawi SK, Methven L, Rastall RA, Niranjan K (2012) Thermal and high hydrostatic pressure inactivation of myrosinase from green cabbage: a kinetic study. Food Chem 131:1240-1247

Giacoppo S, Galuppo M, De Nicola GR, Iori R, Bramanti P, Mazzon E (2015a) 4( $\alpha$-1-rhamnosyloxy)-benzyl isothiocyanate, a bioactive phytochemical that attenuates secondary damage in an experimental model of spinal cord injury. Bioorg Med Chem 23:80-88

Giacoppo S, Galuppo M, Iori R, De Nicola GR, Bramanti P, Mazzon E (2014a) The protective effects of bioactive (RS)glucoraphanin on the permeability of the mice blood-brain barrier following experimental autoimmune encephalomyelitis. Eur Rev Med Pharmacol Sci 18:194-204

Giacoppo S, Galuppo M, Iori R, De Nicola GR, Bramanti P, Mazzon E (2014b) (RS)-glucoraphanin purified from Tuscan black kale and bioactivated with myrosinase enzyme protects against cerebral ischemia/reperfusion injury in rats. Fitoterapia 99:166-177

Giacoppo S, Galuppo M, Iori R, De Nicola GR, Cassata G, Bramanti P, Mazzon E (2013) Protective role of (RS )glucoraphanin bioactivated with myrosinase in an experimental model of multiple sclerosis. CNS Neurosci Ther 19:577-584

Giacoppo S, Galuppo M, Montaut S, Iori R, Rollin P, Bramanti $\mathrm{P}$, Mazzon E (2015b) An overview on neuroprotective effects of isothiocyanates for the treatment of neurodegenerative diseases. Fitoterapia 106:12-21

Giacoppo S, Iori R, Bramanti P, Mazzon E (2017a) Topical moringin cream relieves neuropathic pain by suppression of inflammatory pathway and voltage-gated ion channels in murine model of multiple sclerosis. Mol Pain 13:1744806917724318

Giacoppo S, Rajan TS, De Nicola GR, Iori R, Rollin P, Bramanti $\mathrm{P}$, Mazzon E (2017b) The isothiocyanate isolated from moringa oleifera shows potent anti-inflammatory activity in the treatment of murine subacute parkinson's disease. Rejuvenation Res 20:50-63

Goldberg DS, McGee SJ (2011) Pain as a global public health priority. BMC Public Health 11:770

Guadarrama-Enríquez O, González-Trujano M, Ventura-Martínez R, Rodríguez R, Ángeles-López G, Reyes-Chilpa R, Baenas N, Moreno D (2018) Broccoli sprouts produce abdominal antinociception but not spasmolytic effects like its bioactive metabolite sulforaphane. Biomed Pharmacother 107:1770-1778
Guerrero-Beltrán CE, Calderón-Oliver M, Pedraza-Chaverri J, Chirino YI (2012a) Protective effect of sulforaphane against oxidative stress: recent advances. Exp Toxicol Pathol 64:503-508

Guerrero-Beltrán CE, Mukhopadhyay P, Horváth B, Rajesh M, Tapia E, García-Torres I, Pedraza-Chaverri J, Pacher P (2012b) Sulforaphane, a natural constituent of broccoli, prevents cell death and inflammation in nephropathy. J Nutr Biochem 23:494-500

Gugliandolo A, Giacoppo S, Ficicchia M, Aliquò A, Bramanti P, Mazzon E (2018) Eruca sativa seed extract: A novel natural product able to counteract neuroinflammation. Mol Med Rep 17:6235-6244

Gunn J, Hill MM, Cotten BM, Deer TR (2020) An analysis of biomarkers in patients with chronic pain. Pain Physician 23:E41-E49

Guo J, Li G, Yang L (2020) Role of H2S in pain: Growing evidences of mystification. Eur J Pharmacol 883:173322

Guo R, Chen LH, Xing C, Liu T (2019) Pain regulation by gut microbiota: molecular mechanisms and therapeutic potential. Br J Anaesth 123:637-654

Hanschen FS, Lamy E, Schreiner M, Rohn S (2014) Reactivity and stability of glucosinolates and their breakdown products in foods. Angew Chem Int Ed Engl 53:11430-11450

Hanschen FS, Rohn S, Mewis I, Schreiner M, Kroh LW (2012) Influence of the chemical structure on the thermal degradation of the glucosinolates in broccoli sprouts. Food Chem 130:1-8

Häuser W, Baranowski A, Messelink B, Wesselmann U (2020) Taxonomies for chronic visceral pain. Pain 161:1129-1135

Herr I, Büchler MW (2010) Dietary constituents of broccoli and other cruciferous vegetables: implications for prevention and therapy of cancer. Cancer Treat Rev 36:377-383

Hershman DL, Lacchetti C, Dworkin RH, Lavoie Smith EM, Bleeker J, Cavaletti G, Chauhan C, Gavin P, Lavino A, Lustberg MB (2014) Prevention and management of chemotherapy-induced peripheral neuropathy in survivors of adult cancers: American Society of Clinical Oncology clinical practice guideline. J Clin Oncol 32:1941-1967

Holst B, Williamson G (2004a) A critical review of the bioavailability of glucosinolates and related compounds. Nat Prod Rep 21:425-447

Hosseini A, Abdollahi M (2013) Diabetic neuropathy and oxidative stress: therapeutic perspectives. Oxidat Med Cell Longev 24:258

Hu R, Hebbar V, Kim B-R, Chen C, Winnik B, Buckley B, Soteropoulos P, Tolias P, Hart RP, Kong A-NT (2004) In vivo pharmacokinetics and regulation of gene expression profiles by isothiocyanate sulforaphane in the rat. J Pharmacol Exp Ther 310:263-271

Hylands-White N, Duarte RV, Raphael JH (2017) An overview of treatment approaches for chronic pain management. Rheumatol Int 37:29-42

Innamorato NG, Rojo AI, García-Yagüe ÁJ, Yamamoto M, De Ceballos ML, Cuadrado A (2008) The transcription factor $\mathrm{Nrf} 2$ is a therapeutic target against brain inflammation. J Immunol 181:680-689

Jaafaru MS, Abd Karim NA, Enas ME, Rollin P, Mazzon E, Abdull Razis AF (2018) Protective Effect of Glucosinolates Hydrolytic Products in Neurodegenerative Diseases (NDDs). Nutrients 10:580 
Jazwa A, Rojo AI, Innamorato NG, Hesse M, Fernández-Ruiz J, Cuadrado A (2011) Pharmacological targeting of the transcription factor Nrf2 at the basal ganglia provides disease modifying therapy for experimental parkinsonism. Antioxid Redox Signal 14:2347-2360

Jensen TS, Baron R, Haanpää M, Kalso E, Loeser JD, Rice ASC, Treede RD (2011) A new definition of neuropathic pain. Pain 152:2204-2205

Ji R-R, Chamessian A, Zhang Y-Q (2016) Pain regulation by non-neuronal cells and inflammation. Science 354:572-577

Ji RR, Berta T, Nedergaard M (2013) Glia and pain: is chronic pain a gliopathy? Pain 154(1):S10-s28

Jones R, Frisina C, Winkler S, Imsic M, Tomkins R (2010) Cooking method significantly effects glucosinolate content and sulforaphane production in broccoli florets. Food Chem 123:237-242

Jones RB, Faragher JD, Winkler S (2006) A review of the influence of postharvest treatments on quality and glucosinolate content in broccoli (Brassica oleracea var. italica) heads. Postharvest Biol Technol 41:1-8

Kaczmarek JL, Liu X, Charron CS, Novotny JA, Jeffery EH, Seifried HE, Ross SA, Miller MJ, Swanson KS, Holscher HD (2019a) Broccoli consumption affects the human gastrointestinal microbiota. J Nutr Biochem 63:27-34

Kaushik AS, Strath LJ, Sorge RE (2020) Dietary interventions for treatment of chronic pain: oxidative stress and inflammation. Pain Therapy 1:487-498

Kellingray L, Le Gall G, Doleman JF, Narbad A, Mithen RF (2021) Effects of in vitro metabolism of a broccoli leachate, glucosinolates and S-methylcysteine sulphoxide on the human faecal microbiome. Eur J Nutr 60:2141-2154

Kim D, You B, Jo E-K, Han S-K, Simon MI, Lee SJ (2010) NADPH oxidase 2-derived reactive oxygen species in spinal cord microglia contribute to peripheral nerve injuryinduced neuropathic pain. Proc Natl Acad Sci 107:14851-14856

Kim MW, Kang J-H, Jung HJ, Park SY, Phan THL, Namgung H, Seo S-Y, Yoon YS, Oh SH (2020) Allyl isothiocyanate protects acetaminophen-induced liver injury via NRF2 activation by decreasing spontaneous degradation in hepatocyte. Nutrients 12:3585

Kong L, Tanito M, Huang Z, Li F, Zhou X, Zaharia A, Yodoi J, McGinnis JF, Cao W (2007) Delay of photoreceptor degeneration in tubby mouse by sulforaphane. J Neurochem 101:1041-1052

La Marca M, Beffy P, Della Croce C, Gervasi P, Iori R, Puccinelli E, Longo V (2012) Structural influence of isothiocyanates on expression of cytochrome P450, phase II enzymes, and activation of Nrf2 in primary rat hepatocytes. Food Chem Toxicol 50:2822-2830

Latronico T, Larocca M, Milella S, Fasano A, Rossano R, Liuzzi GM (2021) Neuroprotective potential of isothiocyanates in an in vitro model of neuroinflammation. Inflammopharmacology 29:561-571

Lee HW, Lee CG, Rhee DK, Um SH, Pyo S (2017) Sinigrin inhibits production of inflammatory mediators by suppressing NF- $\mathrm{B} / \mathrm{MAPK}$ pathways or NLRP3 inflammasome activation in macrophages. Int Immunopharmacol 45:163-173
Lee YM, Cho HJ, Ponnuraj SP, Kim J, Kim JS, Kim SG, Park JH (2011) Phenethyl isothiocyanate inhibits 12-O-tetradecanoylphorbol-13-acetate-induced inflammatory responses in mouse skin. J Med Food 14:377-385

Li C, Lun W, Zhao X, Lei S, Guo Y, Ma J, Zhi F (2015) Allicin alleviates inflammation of trinitrobenzenesulfonic acidinduced rats and suppresses P38 and JNK pathways in Caco- 2 cells. Mediat Inflamm 487:434692

Li F, Hullar MA, Beresford SA, Lampe JW (2011) Variation of glucoraphanin metabolism in vivo and ex vivo by human gut bacteria. Br J Nutr 106:408-416

Li L, Whiteman M, Guan YY, Neo KL, Cheng Y, Lee SW, Zhao Y, Baskar R, Tan C-H, Moore PK (2008a) Characterization of a novel, water-soluble hydrogen sulfide-releasing molecule (GYY4137) new insights into the biology of hydrogen sulfide. Circulation 117:2351-2360

Li L, Whiteman M, Guan YY, Neo KL, Cheng Y, Lee SW, Zhao Y, Baskar R, Tan CH, Moore PK (2008b) Characterization of a novel, water-soluble hydrogen sulfide-releasing molecule (GYY4137): new insights into the biology of hydrogen sulfide. Circulation 117:2351-2360

Li S, Hua D, Wang Q, Yang L, Wang X, Luo A, Yang C (2020) The role of bacteria and its derived metabolites in chronic pain and depression: recent findings and research progress. Int J Neuropsychopharmacol 23:26-41

Lim Y-P, Cheng C-H, Chen W-C, Chang S-Y, Hung D-Z, Chen J-J, Wan L, Ma W-C, Lin Y-H, Chen C-Y (2015) Allyl isothiocyanate (AITC) inhibits pregnane $\mathrm{X}$ receptor (PXR) and constitutive androstane receptor (CAR) activation and protects against acetaminophen-and amiodarone-induced cytotoxicity. Arch Toxicol 89:57-72

Lippmann D, Lehmann C, Florian S, Barknowitz G, Haack M, Mewis I, Wiesner M, Schreiner M, Glatt H, BrigeliusFlohé R, Kipp AP (2014) Glucosinolates from pak choi and broccoli induce enzymes and inhibit inflammation and colon cancer differently. Food Funct 5:1073-1081

Logashina YA, Korolkova YV, Kozlov S, Andreev YA (2019) TRPA1 channel as a regulator of neurogenic inflammation and pain: structure, function, role in pathophysiology, and therapeutic potential of ligands. Biochem Mosc 84:101-118

Lopez-Vazquez A, Garcia-Banuelos JJ, Gonzalez-Garibay AS, Urzua-Lozano PE, Del Toro-Arreola S, Bueno-Topete MR, Sanchez-Enriquez S, Munoz-Valle JF, Jave-Suarez LF, Armendariz-Borunda J, Bastidas-Ramirez BE (2017) IRS1 pY612 and Akt-1/PKB pT308 phosphorylation and antiinflammatory effect of diindolylmethane in adipocytes cocultured with macrophages. Med Chem 13:727-733

Lucarini E, Di Pilato V, Parisio C, Micheli L, Toti A, Pacini A, Bartolucci G, Baldi S, Niccolai E, Amedei A, Rossolini GM, Nicoletti C, Cryan JF, O'Mahony SM, Ghelardini C, Di Cesare Mannelli L (2021a) Visceral sensitivity modulation by faecal microbiota transplantation: the active role of gut bacteria in pain persistence. Pain 5:1-8

Lucarini E, Micheli L, Martelli A, Testai L, Calderone V, Ghelardini C, Mannelli LDC (2018a) Efficacy of isothiocyanate-based compounds on different forms of persistent pain. J Pain Res 11:2905

Lucarini E, Micheli L, Trallori E, Citi V, Martelli A, Testai L, De Nicola GR, Iori R, Calderone V, Ghelardini C (2018b) Effect of glucoraphanin and sulforaphane against 
chemotherapy-induced neuropathic pain: Kv7 potassium channels modulation by $\mathrm{H} 2 \mathrm{~S}$ release in vivo. Phytother Res 32:2226-2234

Lucarini E, Pagnotta E, Micheli L, Parisio C, Testai L, Martelli A, Calderone V, Matteo R, Lazzeri L, Di Cesare Mannelli L (2019a) Eruca sativa meal against diabetic neuropathic pain: an H2S-mediated effect of glucoerucin. Molecules 24:3006

Lucarini E, Pagnotta E, Micheli L, Parisio C, Testai L, Martelli A, Calderone V, Matteo R, Lazzeri L, Di Cesare Mannelli L, Ghelardini C (2019b) Eruca sativa meal against diabetic neuropathic pain: an $\mathrm{H} 2 \mathrm{~S}$-mediated effect of glucoerucin. Molecules 24:3006

Lucarini E, Parisio C, Branca JJ, Segnani C, Ippolito C, Pellegrini C, Antonioli L, Fornai M, Micheli L, Pacini A (2020) Deepening the mechanisms of visceral pain persistence: an evaluation of the gut-spinal cord relationship. Cells 9:1772

Lucarini E, Seguella L, Vincenzi M, Parisio C, Micheli L, Toti A, Corpetti C, Del Re A, Squillace S, Maftei D, Lattanzi R, Ghelardini C, Di Cesare Mannelli L, Esposito G (2021b) Role of enteric glia as bridging element between gut inflammation and visceral pain consolidation during acute colitis in rats. Biomedicines 9:1671

Manivannan A, Kim JH, Kim DS, Lee ES, Lee HE (2019) Deciphering the nutraceutical potential of raphanus sativus-a comprehensive overview. Nutrients 11:402

Mannelli LDC, Lucarini E, Micheli L, Mosca I, Ambrosino P, Soldovieri MV, Martelli A, Testai L, Taglialatela M, Calderone V (2017) Effects of natural and synthetic isothiocyanate-based H2S-releasers against chemotherapyinduced neuropathic pain: role of Kv7 potassium channels. Neuropharmacology 121:49-59

Mannelli LDC, Zanardelli M, Failli P, Ghelardini C (2012) Oxaliplatin-induced neuropathy: oxidative stress as pathological mechanism. Protective effect of silibinin. J Pain 13:276-284

Mäntyselkä P, Kumpusalo E, Ahonen R, Kumpusalo A, Kauhanen J, Viinamäki H, Halonen P, Takala J (2001) Pain as a reason to visit the doctor: a study in Finnish primary health care. Pain 89:175-180

Marchev AS, Dimitrova PA, Burns AJ, Kostov RV, DinkovaKostova AT, Georgiev MI (2017) Oxidative stress and chronic inflammation in osteoarthritis: can NRF2 counteract these partners in crime? Ann N Y Acad Sci 1401:114-135

Martelli A, Citi V, Testai L, Brogi S, Calderone V (2020a) Organic isothiocyanates as hydrogen sulfide donors. Antioxid Redox Signal 32:110-144

Martelli A, Testai L, Breschi MC, Lawson K, McKay NG, Miceli F, Taglialatela M, Calderone V (2013) Vasorelaxation by hydrogen sulphide involves activation of Kv7 potassium channels. Pharmacol Res 70:27-34

Martelli A, Testai L, Citi V, Marino A, Bellagambi FG, Ghimenti S, Breschi MC, Calderone V (2014) Pharmacological characterization of the vascular effects of aryl isothiocyanates: is hydrogen sulfide the real player? Vascul Pharmacol 60:32-41

Marzocco S, Calabrone L, Adesso S, Larocca M, Franceschelli S, Autore G, Martelli G, Rossano R (2015) Anti-inflammatory activity of horseradish (Armoracia rusticana) root extracts in LPS-stimulated macrophages. Food Funct 6:3778-3788

Mein JR, James DR, Lakkanna S (2012) Induction of phase 2 antioxidant enzymes by broccoli sulforaphane: perspectives in maintaining the antioxidant activity of vitamins A, C, and E. Front Genet 3:7

Miceli F, Soldovieri MV, Martire M, Taglialatela M (2008) Molecular pharmacology and therapeutic potential of neuronal Kv7-modulating drugs. Curr Opin Pharmacol 8:65-74

Milligan ED, Watkins LR (2009) Pathological and protective roles of glia in chronic pain. Nat Rev Neurosci 10:23-36

Minerbi A, Gonzalez E, Brereton NJB, Anjarkouchian A, Dewar K, Fitzcharles M-A, Chevalier S, Shir Y (2019a) Altered microbiome composition in individuals with fibromyalgia. Pain 160:2589-2602

Mohammed ED, El-Naga RN, Lotfy RA, Al-Gendy AA, ElDemerdash E (2017) Anti-fibrotic potential of a Matthiola arabica isothiocyanates rich fraction: impact on oxidative stress, inflammatory and fibrosis markers. Pharmazie 72:614-624

Morales-Soto W, Gulbransen BD (2019) Enteric glia: a new player in abdominal pain. Cell Mol Gastroenterol Hepatol $7: 433-445$

Naik AK, Tandan SK, Dudhgaonkar SP, Jadhav SH, Kataria M, Prakash VR, Kumar D (2006) Role of oxidative stress in pathophysiology of peripheral neuropathy and modulation by N-acetyl-L-cysteine in rats. Eur J Pain 10:573-579

Negi G, Kumar A, Sharma SS (2011) Nrf2 and NF- $\mathrm{B}$ modulation by sulforaphane counteracts multiple manifestations of diabetic neuropathy in rats and high glucose-induced changes. Curr Neurovasc Res 8:294-304

Nicholas M, Vlaeyen JWS, Rief W, Barke A, Aziz Q, Benoliel R, Cohen M, Evers S, Giamberardino MA, Goebel A, Korwisi B, Perrot S, Svensson P, Wang SJ, Treede RD (2019) The IASP classification of chronic pain for ICD-11: chronic primary pain. Pain 160:28-37

Nodera H, Spieker A, Sung M, Rutkove S (2011) Neuroprotective effects of Kv7 channel agonist, retigabine, for cisplatin-induced peripheral neuropathy. Neurosci Lett 505:223-227

Nugrahedi PY, Verkerk R, Widianarko B, Dekker M (2015) A mechanistic perspective on process-induced changes in glucosinolate content in Brassica vegetables: a review. Crit Rev Food Sci Nutr 55:823-838

O’Mahony SM, Dinan TG, Cryan JF (2017) The gut microbiota as a key regulator of visceral pain. Pain 158:S19-S28

Ono K, Akaike T, Sawa T, Kumagai Y, Wink DA, Tantillo DJ, Hobbs AJ, Nagy P, Xian M, Lin J (2014) Redox chemistry and chemical biology of H2S, hydropersulfides, and derived species: implications of their possible biological activity and utility. Free Radical Biol Med 77:82-94

Perrot S, Cohen M, Barke A, Korwisi B, Rief W, Treede RD (2019) The IASP classification of chronic pain for ICD-11: chronic secondary musculoskeletal pain. Pain 160:77-82

Pietri R, Román-Morales E, López-Garriga J (2011) Hydrogen sulfide and hemeproteins: knowledge and mysteries. Antioxid Redox Signal 15:393-404

Pittayanon R, Lau JT, Yuan Y, Leontiadis GI, Tse F, Surette M, Moayyedi P (2019) Gut microbiota in patients with 
irritable bowel syndrome-a systematic review. Gastroenterology 157:97-108

Plog BA, Nedergaard M (2018) The glymphatic system in central nervous system health and disease: past, present, and future. Annu Rev Pathol 13:379-394

Pusceddu MM, Gareau MG (2018) Visceral pain: gut microbiota, a new hope? J Biomed Sci 25:1-8

Qin J, Li R, Raes J, Arumugam M, Burgdorf KS, Manichanh C, Nielsen T, Pons N, Levenez F, Yamada T, Mende DR, Li J, Xu J, Li S, Li D, Cao J, Wang B, Liang H, Zheng H, Xie Y, Tap J, Lepage P, Bertalan M, Batto JM, Hansen T, Le Paslier D, Linneberg A, Nielsen HB, Pelletier E, Renault P, Sicheritz-Ponten T, Turner K, Zhu H, Yu C, Li S, Jian M, Zhou Y, Li Y, Zhang X, Li S, Qin N, Yang H, Wang J, Brunak S, Doré J, Guarner F, Kristiansen K, Pedersen O, Parkhill J, Weissenbach J, Bork P, Ehrlich SD, Wang J (2010) A human gut microbial gene catalogue established by metagenomic sequencing. Nature 464:59-65

Radojčić Redovniković I, Glivetić T, Delonga K, VorkapićFurač J (2008) Glucosinolates and their potential role in plant. Period Biol 110:297-309

Rahimi R, Baghaei A, Baeeri M, Amin G, Shams-Ardekani MR, Khanavi M, Abdollahi M (2013) Promising effect of Magliasa, a traditional Iranian formula, on experimental colitis on the basis of biochemical and cellular findings. World J Gastroenterol 19:1901-1911

Redondo A, Chamorro PAF, Riego G, Leánez S, Pol O (2017) Treatment with sulforaphane produces antinociception and improves morphine effects during inflammatory pain in mice. J Pharmacol Exp Ther 363:293-302

Roa-Coria JE, Pineda-Farias JB, Barragán-Iglesias P, QuiñonezBastidas GN, Zúñiga-Romero Á, Huerta-Cruz JC, ReyesGarcía JG, Flores-Murrieta FJ, Granados-Soto V, RochaGonzález HI (2019) Possible involvement of peripheral TRP channels in the hydrogen sulfide-induced hyperalgesia in diabetic rats. BMC Neurosci 20:1-17

Robiquet P, Boutron F (1831) Sur la semence de moutarde. J Pharm Chim 17:279-282

Sajja RK, Kaisar MA, Vijay V, Desai VG, Prasad S, Cucullo L (2018) In vitro modulation of redox and metabolism interplay at the brain vascular endothelium: genomic and proteomic profiles of sulforaphane activity. Sci Rep 8:1-13

Saleh HA, Yousef MH, Abdelnaser A (2021) The anti-inflammatory properties of phytochemicals and their effects on epigenetic mechanisms involved in TLR4/NF- $\kappa B-M e d i-$ ated Inflammation. Front Immunol 12:489

Sánchez-Domínguez B, Bullón P, Román-Malo L, MarínAguilar F, Alcocer-Gómez E, Carrión AM, SánchezAlcazar JA, Cordero MD (2015) Oxidative stress, mitochondrial dysfunction and inflammation common events in skin of patients with Fibromyalgia. Mitochondrion 21:69-75

Schleifenbaum J, Köhn C, Voblova N, Dubrovska G, Zavarirskaya O, Gloe T, Crean CS, Luft FC, Huang Y, Schubert R (2010) Systemic peripheral artery relaxation by KCNQ channel openers and hydrogen sulfide. J Hypertens 28:1875-1882

Sestito S, Pruccoli L, Runfola M, Citi V, Martelli A, Saccomanni G, Calderone V, Tarozzi A, Rapposelli S (2019) Design and synthesis of $\mathrm{H}(2) \mathrm{S}$-donor hybrids: A new treatment for Alzheimer's disease? Eur J Med Chem 184:111745

Shakour ZT, Shehab NG, Gomaa AS, Wessjohann LA, Farag MA (2021) Metabolic and biotransformation effects on dietary glucosinolates, their bioavailability, catabolism and biological effects in different organisms. Biotechnol Adv 14:107784

Shapiro TA, Fahey JW, Wade KL, Stephenson KK, Talalay P (1998) Human metabolism and excretion of cancer chemoprotective glucosinolates and isothiocyanates of cruciferous vegetables. Cancer Epidemiol Prevent Biomark 7:1091-1100

Shirai Y, Fujita Y, Hashimoto R, Ohi K, Yamamori H, Yasuda Y, Ishima T, Suganuma H, Ushida Y, Takeda M, Hashimoto K (2015) Dietary intake of sulforaphane-rich broccoli sprout extracts during juvenile and adolescence can prevent phencyclidine-induced cognitive deficits at adulthood. PLoS ONE 10:e0127244

Shock T, Badang L, Ferguson B, Martinez-Guryn K (2021) The interplay between diet, gut microbes, and host epigenetics in health and disease. J Nutr Biochem 95:108631

Sikorska-Zimny K, Beneduce L (2020) The glucosinolates and their bioactive derivatives in Brassica: a review on classification, biosynthesis and content in plant tissues, fate during and after processing, effect on the human organism and interaction with the gut microbiota. Crit Rev Food Sci Nutr 1-28:2544-2571

Sønderby IE, Geu-Flores F, Halkier BA (2010) Biosynthesis of glucosinolates-gene discovery and beyond. Trends Plant Sci 15:283-290

Spassov SG, Donus R, Ihle PM, Engelstaedter H, Hoetzel A, Faller S (2017) Hydrogen sulfide prevents formation of reactive oxygen species through PI3K/Akt signaling and limits ventilator-induced lung injury. Oxidat mEdicine Cell Longev 58:596

Subedi L, Venkatesan R, Kim SY (2017) Neuroprotective and anti-inflammatory activities of allyl isothiocyanate through attenuation of JNK/NF- $\kappa \mathrm{B} / \mathrm{TNF}-\alpha$ signaling. Int J Mol Sci 18:1423

Szabo C, Ransy C, Módis K, Andriamihaja M, Murghes B, Coletta C, Olah G, Yanagi K, Bouillaud F (2014) Regulation of mitochondrial bioenergetic function by hydrogen sulfide. Part I. Biochemical and physiological mechanisms. Br J Pharmacol 171:2099-2122

Taljaard T (1993) Cabbage poisoning in ruminants. J S Afr Vet Assoc 64:96-100

Tanii H (2017a) Allyl nitrile: toxicity and health effects. J Occup Health 59:104-111

Tanito M, Masutani H, Kim Y-C, Nishikawa M, Ohira A, Yodoi J (2005) Sulforaphane induces thioredoxin through the antioxidant-responsive element and attenuates retinal light damage in mice. Invest Ophthalmol vis Sci 46:979-987

Tarozzi A, Angeloni C, Malaguti M, Morroni F, Hrelia S, Hrelia P (2013) Sulforaphane as a potential protective phytochemical against neurodegenerative diseases. Oxid Med Cell Longev 14:415078

Telang U, Ji Y, Morris ME (2009) ABC transporters and isothiocyanates: potential for pharmacokinetic diet-drug interactions. Biopharm Drug Dispos 30:335-344

Treede R-D, Rief W, Barke A, Aziz Q, Bennett MI, Benoliel R, Cohen M, Evers S, Finnerup NB, First MB, Giamberardino 
MA, Kaasa S, Korwisi B, Kosek E, Lavand'homme P, Nicholas M, Perrot S, Scholz J, Schug S, Smith BH, Svensson P, Vlaeyen JWS, Wang S-J (2019) Chronic pain as a symptom or a disease: the IASP classification of chronic pain for the international classification of diseases (ICD-11). Pain 160:19-27

Treede RD, Jensen TS, Campbell JN, Cruccu G, Dostrovsky JO, Griffin JW, Hansson P, Hughes R, Nurmikko T, Serra J (2008) Neuropathic pain: redefinition and a grading system for clinical and research purposes. Neurology 70:1630-1635

Tripathi M, Mishra A (2007) Glucosinolates in animal nutrition: a review. Anim Feed Sci Technol 132:1-27

Tsubota-Matsunami M, Noguchi Y, Okawa Y, Sekiguchi F, Kawabata A (2012) Colonic hydrogen sulfide-induced visceral pain and referred hyperalgesia involve activation of both Cav3. 2 and TRPA1 channels in mice. J Pharmacol Sci 119:293-296

Vauzour D, Buonfiglio M, Corona G, Chirafisi J, Vafeiadou K, Angeloni C, Hrelia S, Hrelia P, Spencer JP (2010) Sulforaphane protects cortical neurons against 5-S-cysteinyldopamine-induced toxicity through the activation of ERK1/2, Nrf-2 and the upregulation of detoxification enzymes. Mol Nutr Food Res 54:532-542

Venditti A, Bianco A (2020) Sulfur-containing secondary metabolites as neuroprotective agents. Curr Med Chem 27:4421-4436

Verkerk R, Schreiner M, Krumbein A, Ciska E, Holst B, Rowland I, De Schrijver R, Hansen M, Gerhäuser C, Mithen R (2009) Glucosinolates in Brassica vegetables: the influence of the food supply chain on intake, bioavailability and human health. Mol Nutr Food Res 53:S219-S219

Vila AV, Imhann F, Collij V, Jankipersadsing SA, Gurry T, Mujagic Z, Kurilshikov A, Bonder MJ, Jiang X, Tigchelaar EF (2018) Gut microbiota composition and functional changes in inflammatory bowel disease and irritable bowel syndrome. Sci Transl Med 10:8914

Wang C, Wang C (2017) Anti-nociceptive and anti-inflammatory actions of sulforaphane in chronic constriction injuryinduced neuropathic pain mice. Inflammopharmacology 25:99-106

Wang F, Ma SB, Tian ZC, Cui YT, Cong XY, Wu WB, Wang FD, Li ZZ, Han WJ, Wang TZ, Sun ZC, Zhang FL, Xie RG, Wu SX, Luo C (2021) Nociceptor-localized cGMP-dependent protein kinase $\mathrm{I}$ is a critical generator for central sensitization and neuropathic pain. Pain 162:135-151

Wang H-S, Pan Z, Shi W, Brown BS, Wymore RS, Cohen IS, Dixon JE, McKinnon D (1998) KCNQ2 and KCNQ3 potassium channel subunits: molecular correlates of the M-channel. Science 282:1890-1893

Waterman C, Cheng DM, Rojas-Silva P, Poulev A, Dreifus J, Lila MA, Raskin I (2014) Stable, water extractable isothiocyanates from Moringa oleifera leaves attenuate inflammation in vitro. Phytochemistry 103:114-122

Wu L, Noyan Ashraf MH, Facci M, Wang R, Paterson PG, Ferrie A, Juurlink BH (2004) Dietary approach to attenuate oxidative stress, hypertension, and inflammation in the cardiovascular system. Proc Natl Acad Sci USA 101:7094-7099
Xiao Q, Ying J, Xiang L, Zhang C (2018) The biologic effect of hydrogen sulfide and its function in various diseases. Medicine (baltimore) 97:13065

Yanaka A (2017) Role of sulforaphane in protection of gastrointestinal tract against $H$. pylori and NSAID-induced oxidative stress. Curr Pharm Des 23:4066-4075

Yanaka A, Fahey JW, Fukumoto A, Nakayama M, Inoue S, Zhang S, Tauchi M, Suzuki H, Hyodo I, Yamamoto M (2009) Dietary sulforaphane-rich broccoli sprouts reduce colonization and attenuate gastritis in Helicobacter pyloriinfected mice and humans. Cancer Prev Res (phila) 2:353-360

Yang H-Y, Wu Z-Y, Bian J-S (2014a) Hydrogen sulfide inhibits opioid withdrawal-induced pain sensitization in rats by down-regulation of spinal calcitonin gene-related peptide expression in the spine. Int $\mathbf{J}$ Neuropsychopharmacol 17:1387-1395

Yang H-Y, Wu Z-Y, Wood M, Whiteman M, Bian J-S (2014b) Hydrogen sulfide attenuates opioid dependence by suppression of adenylate cyclase/cAMP pathway. Antioxid Redox Signal 20:31-41

Yao W, Zhang JC, Ishima T, Dong C, Yang C, Ren Q, Ma M, Han M, Wu J, Suganuma H, Ushida Y, Yamamoto M, Hashimoto K (2016) Role of Keap1-Nrf2 signaling in depression and dietary intake of glucoraphanin confers stress resilience in mice. Sci Rep 6:30659

Ye L, Dinkova-Kostova AT, Wade KL, Zhang Y, Shapiro TA, Talalay P (2002) Quantitative determination of dithiocarbamates in human plasma, serum, erythrocytes and urine: pharmacokinetics of broccoli sprout isothiocyanates in humans. Clin Chim Acta 316:43-53

Zeber-Lubecka N, Kulecka M, Ambrozkiewicz F, Paziewska A, Goryca K, Karczmarski J, Rubel T, Wojtowicz W, Mlynarz P, Marczak L, Tomecki R, Mikula M, Ostrowski J (2016) Limited prolonged effects of rifaximin treatment on irritable bowel syndrome-related differences in the fecal microbiome and metabolome. Gut Microbes 7:397-413

Zhang F, Liu Y, Zhang D, Fan X, Shao D, Li H (2019) Suppression of $\mathrm{KCNQ} / \mathrm{M}$ potassium channel in dorsal root ganglia neurons contributes to the development of osteoarthritic pain. Pharmacology 103:257-262

Zhang P, Li T, Liu C, Sindi M, Cheng X, Qi S, Liu X, Yan Y, Bao Y, Brand-Saberi B, Yang W, Wang G, Yang X (2021) Nano-sulforaphane attenuates PhIP-induced early abnormal embryonic neuro-development. Ann Anat 233:151617

Zhao J, Moore AN, Clifton GL, Dash PK (2005a) Sulforaphane enhances aquaporin-4 expression and decreases cerebral edema following traumatic brain injury. J Neurosci Res 82:499-506

Zhou C, Poulton E-J, Grün F, Bammler TK, Blumberg B, Thummel KE, Eaton DL (2007) The dietary isothiocyanate sulforaphane is an antagonist of the human steroid and xenobiotic nuclear receptor. Mol Pharmacol 71:220-229

Publisher's Note Springer Nature remains neutral with regard to jurisdictional claims in published maps and institutional affiliations. 